\title{
The Hungarian Model: Hungarian Crisis Management in View of the Mediterranean Way*
}

\author{
György Matolcsy - Dániel Palotai
}

This paper examines the crisis management measures used by Mediterranean euro area countries and Hungary. Such a comparison is justified, because in certain periods of the crisis these countries faced similar challenges necessitating rapid economic policy intervention as previous practices proved to be unsustainable. However, the tools used - and thus also the results - were different. After 2010, Hungary sought to achieve economic balance by improving employment and growth, mainly driven by a tax reform and structural reforms of the budget and, from 2013, after the turnaround in monetary policy, also supported by targeted measures of the Magyar Nemzeti Bank (the Central Bank of Hungary). Overall, the harmonisation between the two main branches of economic policy gave rise to an innovative, growth-friendly economic policy, which since 2013 has created a balance between macro-financial equilibrium and growth not seen for a long time. By contrast, the Mediterranean countries using the euro basically opted for traditional crisis management: they sacrificed growth for balance, yet even the latter was achieved much later than in Hungary. In their case, recovery was also hampered by monetary policy constraints due to euro area membership. The targeted Hungarian steps may provide a good example to other countries facing similar challenges.

Journal of Economic Literature (JEL) codes: E52, E58, E62, H21, 023

Keywords: fiscal policy, monetary policy, economic policy coordination, Hungarian economic history, Laffer curve, crisis management

\section{Introduction}

The global financial crisis posed an enormous challenge, primarily for those countries where economic growth had to be restored in parallel with fiscal and macro-financial stabilisation. Traditional crisis management tools are only able to

\footnotetext{
* The papers in this issue contain the views of the authors which are not necessarily the same as the official views of the Magyar Nemzeti Bank.

György Matolcsy is the Governor of the Magyar Nemzeti Bank.

Dániel Palotai is Executive Director and Chief Economist of the Magyar Nemzeti Bank. E-mail: palotaid@mnb.hu

The authors wish to thank Gergely Baksay, Ákos Szalai, Róbert Hausmann, Dávid Berta and Gábor Meizer for their contribution to this paper.

The Hungarian manuscript was received on 4 April 2018.
}

DOI: http://doi.org/10.25201/FER.17.2.542 
achieve one of these goals, and only at the expense of the other. The introduction of a new model to Hungarian economic policy with innovative and targeted tools after 2010 resulted in effective crisis management in an international comparison, illustrating that with the appropriate approach, this crisis management dilemma can be resolved, and economic balance and growth can be achieved at the same time.

Ten years after the crisis, it is now time to draw the lessons. Economists are still reassessing and developing economic models by integrating previously neglected areas, such as the financial intermediary system, inequalities or the impact of the cyclical variation in fiscal multipliers. In a similar fashion, economic policymakers need to take stock of what they learned about crisis management and how to avoid a new crisis.

The study compares the Hungarian crisis management measures and results to the experiences of those European countries which, in many respects, faced similar policy challenges during the crisis. The comparison is based on the Mediterranean countries (Greece, Italy, Portugal and Spain: ClubMed), where - due to private sector or budgetary reasons - a similarly rapid economic policy intervention was necessary during the crisis, as the then prevailing practices had proved to be unsustainable.

The Mediterranean countries ${ }^{1}$ faced similar economic problems as Hungary. The financial crisis was especially severe in the countries that struggled with macrofinancial imbalances and financing difficulties, and whose room for economic policy manoeuvre was constrained. The pre-crisis situation was not exactly the same in all of the Mediterranean countries under review, but over time similar problems emerged, even though as euro area members they could rely on the support of the European Central Bank to some extent. The banking systems faced problems in all four countries, and large real estate bubbles formed, especially in Spain and Greece. Italy and Greece had the highest levels of public debt in the European Union (Sávai - Kiss 2017). Greece, Portugal and Spain were characterised by a current account deficit of around or over 10 per cent of GDP. The labour market participation rate and employment were substantially lower in Greece and Italy than the Western European average (Table 1).

\footnotetext{
${ }^{1}$ The analysis needs to take into account the fact that these countries cannot be treated as a homogeneous group in every respect, as the source of macroeconomic instability as well as the tools chosen differed in a number of aspects.
} 
Table 1

Main macroeconomic indicators of Hungary and the ClubMed countries as an average of $2008-2010$

\begin{tabular}{l|c|c|c|c|c} 
& Hungary & Greece & Italy & Portugal & Spain \\
\hline $\begin{array}{l}\text { Government debt (\% } \\
\text { of GDP) }\end{array}$ & 76.5 & 127.4 & 110.1 & 83.8 & 50.8 \\
\hline Real GDP growth (\%) & -1.7 & -3.4 & -1.6 & -0.3 & -0.8 \\
\hline $\begin{array}{l}\text { Average annual } \\
\text { inflation (\%) }\end{array}$ & 4.9 & 3.4 & 2.0 & 1.1 & 2.0 \\
\hline $\begin{array}{l}\text { Net external debt (\% } \\
\text { of GDP) }\end{array}$ & 54.1 & 86.1 & 42.0 & 79.6 & 86.8 \\
\hline $\begin{array}{l}\text { Budget balance (\% of } \\
\text { GDP) }\end{array}$ & -4.2 & -12.2 & -4.1 & -8.3 & -8.3 \\
\hline $\begin{array}{l}\text { Unemployment rate } \\
\text { (\%) }\end{array}$ & 9.7 & 10.0 & 7.6 & 10.5 & 16.4 \\
\hline \begin{tabular}{l} 
Employment rate (\%) \\
\hline $\begin{array}{l}\text { 5-year CDS spread } \\
\text { (bps) }\end{array}$
\end{tabular}$\quad 55.4$ & 60.4 & 57.6 & 66.5 & 61.1 \\
\hline $\begin{array}{l}\text { Current account } \\
\text { balance (\% of GDP) }\end{array}$ & -2.5 & -12.9 & -2.7 & -10.9 & 112.1 \\
\hline \begin{tabular}{l} 
Source: Eurostat, MNB \\
\hline
\end{tabular}
\end{tabular}

As a result of the flawed economic policy of 2002-2008, Hungary faced all of the problems characteristic of the Mediterranean countries at the onset of the crisis (Matolcsy 2008). Hungary had one of the lowest employment rates in the EU, a most severe factor inhibiting production, while also experiencing a persistently high general government deficit and current account deficit (twin deficit). The unsustainability of the Hungarian economic policy had been revealed earlier, already in 2006, and the lack of structural reforms as well as the flawed structure of the fiscal adjustment implemented at that time reduced the growth rate of the Hungarian economy to around 0 even before the crisis. By the end of 2008 , Hungary was characterised by weakened economic fundamentals and limited room for economic policy manoeuvre and was confronted with the global financial and economic depression, which resulted in a synchronised financing, debt and real economy crisis. As a consequence of the high external and internal indebtedness, the lack of market confidence and the freezing of the government securities market, Hungary was among the first countries which had to request financial assistance from the IMF and the European Union.

On account of the global financial crisis and the 2011 debt crisis in the peripheral countries, real economy output slumped, causing turmoil in the financial system and the functioning of money markets through various channels. As a general consequence, willingness to lend and to take risks declined, while the risk of the prolonged deflation emerged in the countries which were more affected by 
the crisis. Meanwhile, government bond yields in certain euro area countries significantly surged, and due to the losses on government securities holdings on their balance sheets as well as non-performing loans, commercial banks curbed lending. In many places, the economic crisis was coupled with a political crisis, and finding the appropriate economic policy responses was also difficult because of frequent changes of government in some countries (after 2010, there were six different heads of government in Greece, and five in Italy).

After 2010, Hungary introduced growth-friendly fiscal reforms and, starting from 2013, the Magyar Nemzeti Bank (MNB) achieved a monetary policy turnaround with its innovative, targeted measures. As a result, the country's crisis management proved to be more successful than in Mediterranean peers. By contrast, the Mediterranean countries sought to consolidate their budgets through traditional austerity measures, and their monetary policy was determined by the European Central Bank (ECB), which only belatedly used unconventional tools. We believe that the fiscal, employment and growth figures clearly show that the growth-friendly Hungarian crisis management model based on the harmony between fiscal and monetary policy was more effective than the traditional approach used in the Mediterranean countries. Reforms similar to those in Hungary would probably have reduced the growth sacrifice of stabilisation and thus borne fruit sooner in their case, too. The comparison should take into account the fact that the Hungarian measures have been based on strong political continuity and stability since 2010 .

This paper highlights the differences in the crisis management practices of the Mediterranean countries and Hungary, and how effective they proved with respect to the achievement of the objectives. The second chapter presents the basic crisis management dilemma, i.e. that there is often a trade-off between stimulating economic growth and macro-financial stabilisation, and how this dilemma can be resolved. The third chapter lists the major fiscal measures, while the fourth details monetary policy steps. Both sections demonstrate that there were significant differences in the crisis management efforts. With respect to monetary policy, this was partly given for euro area members, since the use of a single currency does not allow autonomous crisis management, but the independence and room for manoeuvre of fiscal policy were very similar. Chapter 5 describes the results of the reforms, i.e. the macroeconomic situation achieved in recent years. Finally, Chapter 6 summarises the findings. 


\section{The basic crisis management dilemma: balance or growth?}

The largest challenge faced by the unstable countries during the crisis was to mitigate the recession and at the same time restore economic balance or, more concretely, reduce fiscal deficits. Countries with a stable macro-financial balance could afford to increase their budget deficit to cushion effects of the economic downturn (i.e. to pursue a countercyclical economic policy). This was typical for the advanced countries, while the Mediterranean countries also tried to adopt this approach (Figure 1). However, in 2010 euro area economies started focusing on improving the fiscal balance, neglecting the effects on the real economy, assuming that reducing the deficit does not materially affect economic growth. However, this assumption and the resulting procyclical fiscal policy proved to be one of the key mistakes in European crisis management.

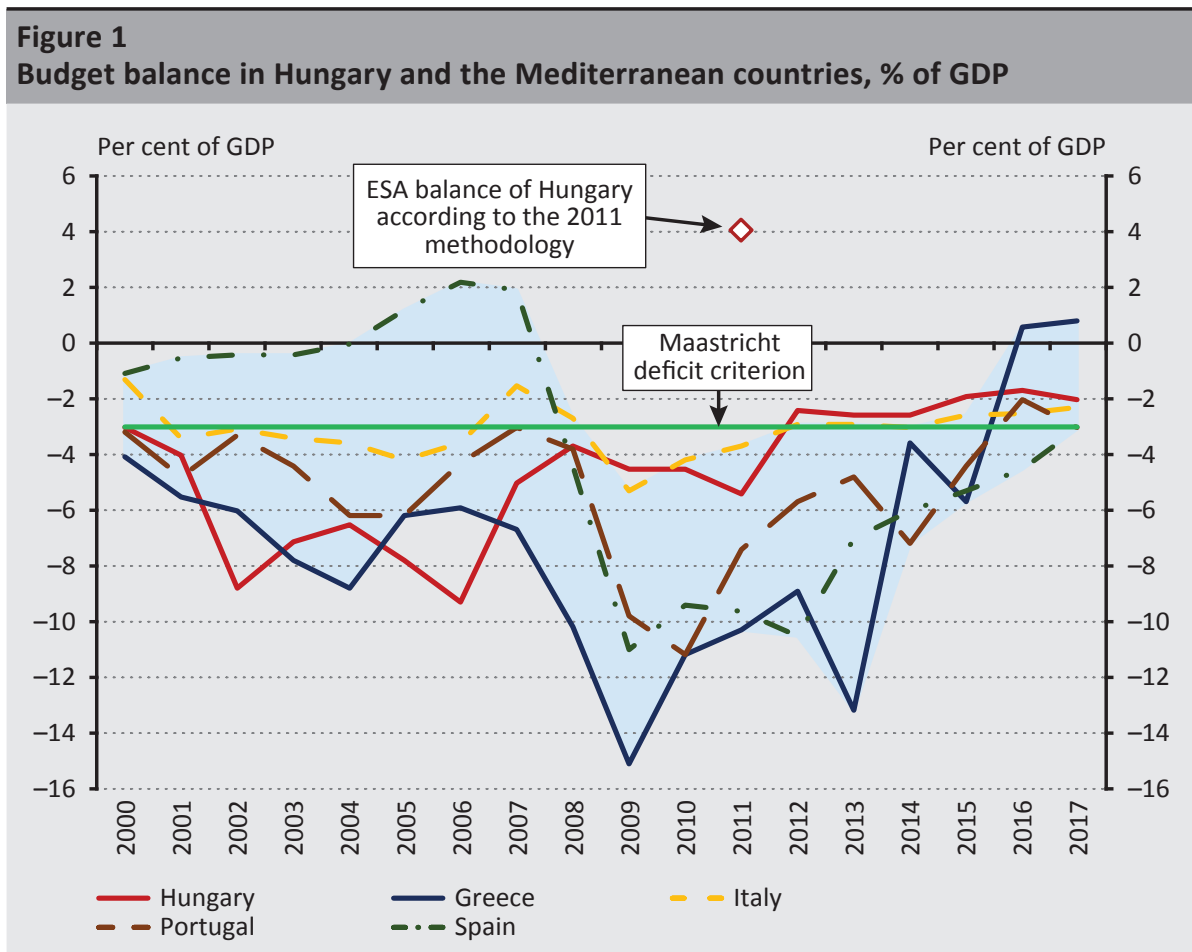

Note: In the graphs that enable international comparison the blue bands show the area indicated between the lowest and the highest recorded yearly value of the Mediterranean countries.

Source: Edited based on Eurostat data 
Those countries applying austerity measures strongly underestimated fiscal multipliers in a recessionary environment. The fiscal multiplier measures the effect of a unit change in government expenditure or revenues on economic growth. However, among other factors, the size of the multiplier depends strongly on the cyclical position of the economy, and it is the strongest in times of recession (Ilzetzki et al. 2013; Auerbach - Gorodnichenko 2012). This means that in a crisis, the deficitreducing measures without economic stimulus elements hamper economic growth to such an extent that they undermine fiscal consolidation through the contraction of tax revenues.

Empirical evidence shows that the economic downturn was aggravated by fiscal austerity more than expected. Blanchard and Leigh (2013) concluded that the International Monetary Fund (IMF) estimated the fiscal multiplier to be substantially lower than in reality, thereby also underestimating the recession caused by the fiscal adjustment. Their study showed that the larger the fiscal consolidation, the larger the shortfall in growth compared to the forecast. In Greece, for example, GDP growth in 2010-2011 was by 7 per cent lower than projected, while the budget balance was more or less in line with expectations. The authors estimated the fiscal multiplier to be between 0.9 and 1.7 and not around the level of 0.5 previously assumed by the IMF.

Without austerity measures, the recession could have been largely avoided, and a tax reform would have even boosted economic growth. House et al. (2017) modelled how much smaller the downturn would have been in the European Union Member States without austerity measures (raising taxes on labour, cutting wages and pensions). They found that without austerity measures, economic output could have fallen short of its potential level in the Mediterranean euro area countries (and Ireland) by a mere 1 per cent instead of the actual 18 per cent (Figure 2). The authors also point out in their paper that an independent monetary policy would have reduced the downturn by even more. The European Commission's (2013) analysis also attests that a growth-friendly tax reform would have exerted a positive real economic impact in Spain and Italy. 


\section{Figure 2}

The combined economic performance of Mediterranean euro area countries and Ireland relative to the equilibrium with austerity measures (actual data) and without them (estimation)

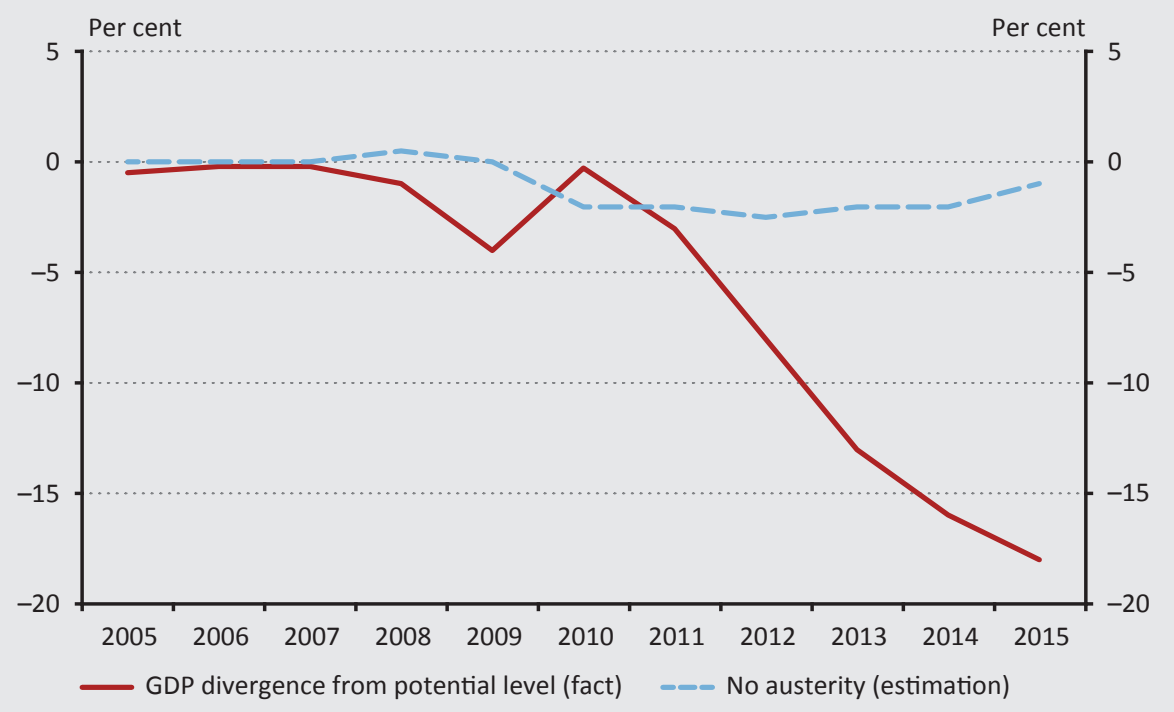

Source: House et al. (2017)

Between 2006 and 2009, i.e. in an earlier period than the Mediterranean countries, Hungary was characterised by austerity in fiscal policy that deepened the crisis. Between 2002 and 2006, the Hungarian budget deficit was at unsustainably high levels, at 7.9 per cent of GDP on average. The measures of 2006 aimed at reducing the deficit had a flawed structure, as they were solely based on raising tax revenues, and therefore their impact was similar to the subsequent austerity in Mediterranean countries (Matolcsy 2015). As a result of these measures, in 2007, i.e. the year before the crisis hit, economic growth already dropped to around 0 per cent, and it continued to stagnate below 1 per cent in 2008. The Hungarian budget responded to the real economy recession entailing the global financial crisis in 2009 with a different approach than most European countries. While elsewhere the recession was sought to be mitigated by increasing the deficit, the EU-IMF programmes imposed too tight fiscal measures on Hungary, which stood in stark contrast to the previous loose fiscal policy. This second wave of austerity-based fiscal consolidation focused on decreasing expenditures. International examples showed that in times of crisis, fiscal austerity curbs the economy's performance and deepens the recession especially severely. Partly on account of this, the Hungarian economy saw one of the largest downturns in the European Union in 2009, when GDP declined by 6.6 per cent. Overall, in 2006 and 2009 the Hungarian economy experienced what 
became reality in the Mediterranean countries only after 2009. The flawed timing and structure of fiscal austerity hampered growth and deepened the recession.

The new conservative Government that took office in 2010 performed a fiscal turnaround that reduced the deficit and stimulated economic growth at the same time. The Hungarian fiscal turnaround wished to solve the economic dilemma about the trade-off between economic balance and growth. The dilemma was resolved by the new Government by boosting employment, which not only led to economic growth but thus also to a larger tax base, improving the budget balance. The Government shifted the focus in tax centralisation from taxes on labour to consumption taxes, while also cutting the tax rates and simplifying the tax regime for Hungarian SMEs. On the expenditure side, fiscal balance was supported by the rationalisation of the loose social transfers that served as disincentives to employment (as part of the Széll Kálmán Plans). The details of the tax reform are presented in the next chapter where they are also contrasted with the measures in Mediterranean countries.

All in all, only Hungary managed to improve the budget balance and the dynamics of economic growth at the same time after 2010. Despite the average fiscal adjustment of around 9 per cent of GDP in the Mediterranean countries, their budget deficit was still over the 3 per cent Maastricht threshold in 2015. Meanwhile, the austerity measures also hampered the recovery. The real economy performance of Mediterranean countries continued to gradually deteriorate until 2013, and at the end of 2016, only Hungarian economic output was above the pre-crisis levels among the countries under review (Figure 19).

\subsection{The Laffer curve}

The Laffer curve illustrates the theory that there exists a tax rate that maximises government revenues under certain assumptions. However, a higher rate leads to lower tax revenues. The Laffer curve describes a non-linear relationship, first positive then negative, between the tax rate and the tax revenues realised. ${ }^{2}$

Beyond a point, high tax rates become particularly distortive for both the real economy and the budget. The reversal of the curve, i.e. when the relationship between the two variables turns from positive to negative, is based on the observation that an excessively high tax burden results in a smaller tax base on account of the negative dynamics that appear in such situations (e.g. diminishing labour supply, growing shadow economy). In case labour income is taxed excessively, the willingness to work declines in parallel with the drop in net wages. Depending on the tax rate, this drop may happen at either the intensive or the extensive

\footnotetext{
${ }^{2}$ The theory behind the Laffer curve was present before economist Arthur Laffer used it, but in the 1970s he advocated for the use of the theory in economic policy, pointing out the counterproductive effect of excessive taxation.
} 
margin of labour supply. And in case capital income is taxed excessively, companies' willingness to invest falls on account of the expected decline in profitability.

The tax burden on economic actors is especially relevant in times of crisis. In an environment characterised by subdued demand or liquidity constraints, the fiscal multiplier is typically higher because economic actors are more sensitive to fiscal policy measures in the absence of financing. As a result, the excessive tax burden on income or a tax increase are especially detrimental to economic growth and the budgetary position due to the size of the tax base. Therefore growth-inducing measures, i.e. ones that reduce the tax burden, and a simultaneous budgetary consolidation is warranted to mitigate the crisis, and this stabilises the economy as well as the budget balance through the dynamic positive effects.

According to empirical experience, the Laffer curve peaks at around 50-60 per cent. Before the crisis, the Hungarian tax wedge is likely to have been in the declining part of the curve, however, it has been cut to a more favourable range. The shape (height, slope and skew) of the Laffer curve may vary between countries and periods, as it is substantially influenced by the given national economy's tax regime, the functioning of the tax authority, the extent of tax evasion and the elasticity of taxable income. International experience shows that in the case of the taxes on labour, the curve peaks at a tax rate of around 50-60 per cent (Trabandt - Uhlig 2012). In view of this, it is worth examining where Hungary was on the curve before 2010 and where it is now. In 2009, the average Hungarian tax wedge was 53 per cent for the average wage, while the marginal tax wedge was over 70 per cent. The latter was between 75 and 80 per cent in the mid-2000s. By contrast, the average tax wedge has declined to 45 per cent; in fact, it is even lower (20-43 per cent) in the targeted groups (thanks to the introduction and expansion of the family tax base allowance and the Job Protection Action Plan). The lower tax rate for the targeted social groups (families with children and those who are more vulnerable on the labour market) is consistent with the government's social policy objectives and priorities (improving demographic developments, full employment). The marginal tax wedge has equalled the average tax wedge since the introduction of the flat-rate personal income tax regime (Figure 3 ). 


\section{Figure 3 \\ Illustrative Laffer curves based on international examples, and the Hungarian tax wedge in 2009 and 2018}

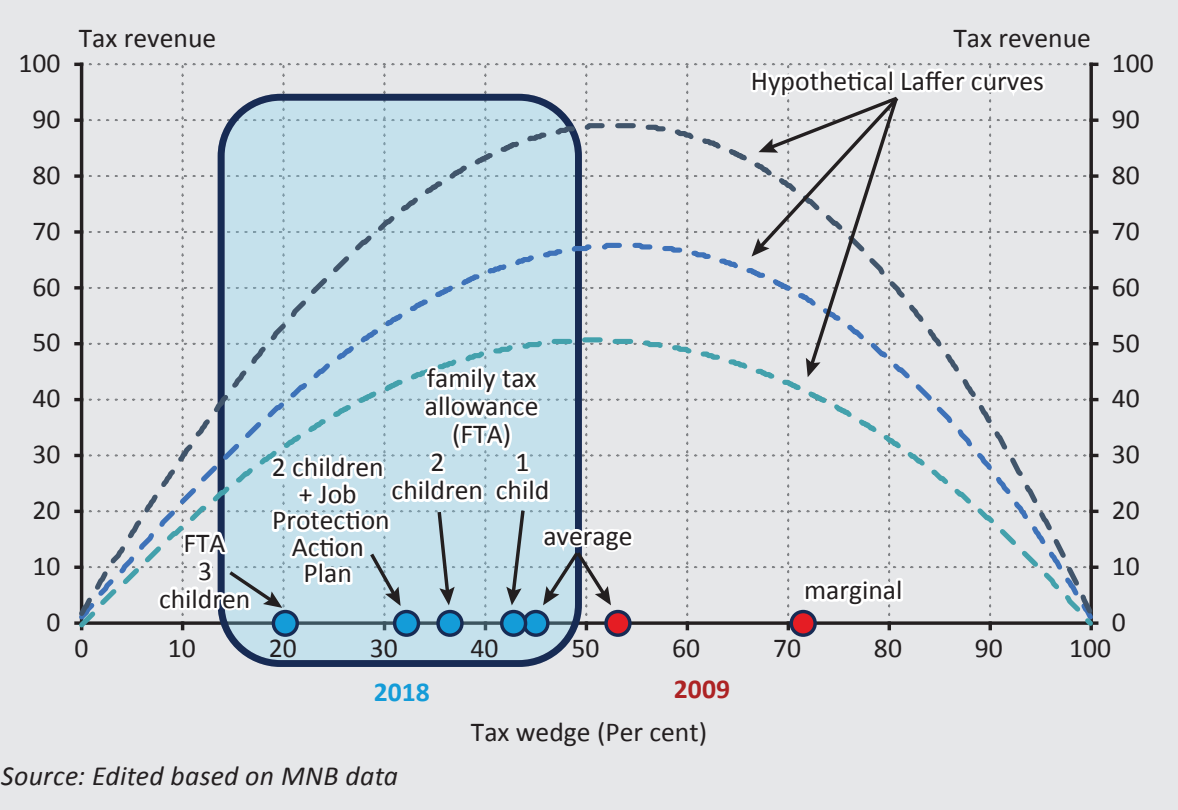

\section{Hungarian crisis management: economic balance and growth}

After 2010, Hungarian fiscal policymakers chose an innovative, growth-friendly approach to crisis management (Matolcsy 2015; Kolozsi et al. 2017). The new economic policymakers soon realised that under these extraordinary circumstances only extraordinary, targeted and unconventional tools can achieve results. This is because the traditional fiscal policy built on austerity measures eliminates economic growth, especially in times of crisis (Eyraud - Weber 2013).

The main objective of the tax system reform was to develop a tax structure that ensures fiscal balance and supports economic growth. Achievement of these two goals in parallel hinged on boosting employment (Palotai 2017). The low employment rate was a structural problem in all of the economies under review, but high unemployment became an even more pressing social issue during the crisis. In the mid-2000s, the Hungarian participation and employment rates were the second lowest in the EU (at 61 and 57 per cent, respectively, on average in 2003-2007), which was largely attributable to the high taxes on labour and the excessively loose social transfer system. This permanently damaged the Hungarian 
economy, as the availability of active labour in adequate quantity and quality is a cornerstone of competitiveness and successful convergence.

Raising the number of people in employment and reducing unemployment became a priority for Hungarian economic policy and the tax reform, and the most important tool for this was shifting the focus of the tax structure from taxes on labour towards consumption taxes (Figure 4) (Szoboszlai et al. 2018). Cutting the personal income tax rate not only encourages employment, this kind of tax shift also improves external competitiveness. This is because lowering the taxes on labour makes producing for export cheaper, while imports become more expensive due to higher value added taxes, which ultimately boosts the competitiveness of the national economy on export markets ${ }^{3}$ (OECD 2010; Prammer 2011). In addition to the tax shift, fiscal balance was ensured by sector-specific crisis taxes levied on more resilient service sectors (banking, insurance, energy, telecommunication and retail sectors). Also, the first steps were taken to improve the efficiency of tax collection, which culminated in parallel with the recovery. The structural transformation of the tax regime was implemented in 2010-2013 and was later followed by parametric finetuning.

\section{Figure 4 \\ Estimated static, cumulative fiscal impact of the Hungarian tax reforms after 2010 by tax types}

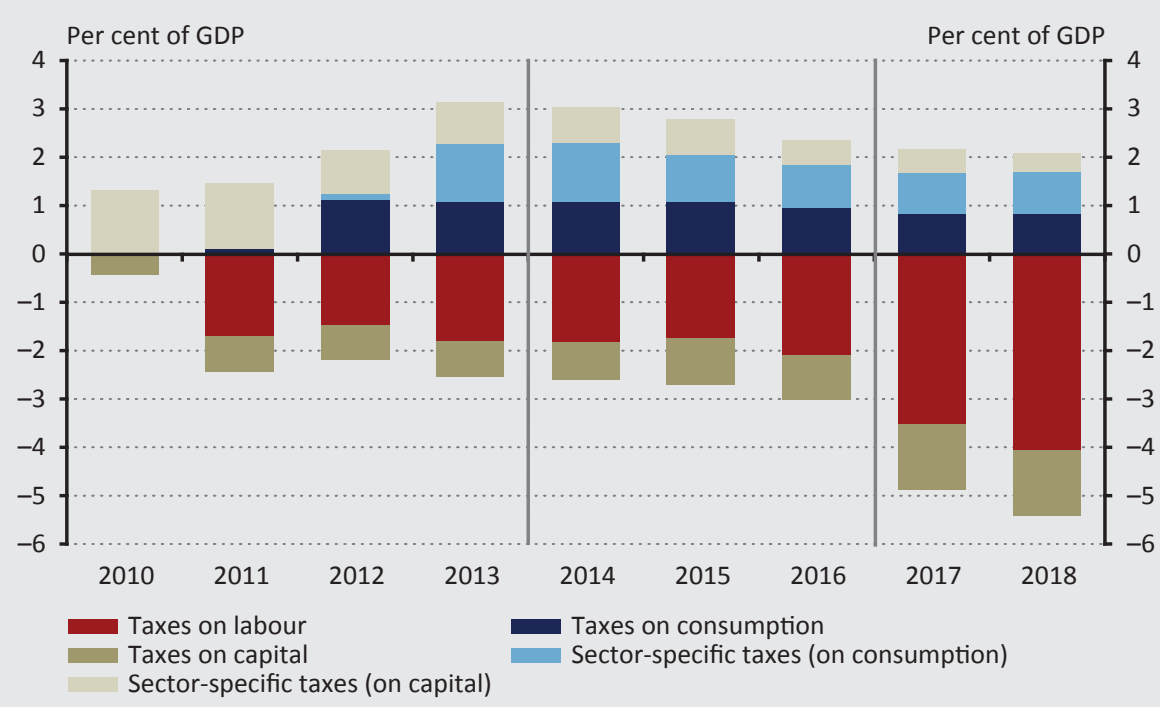

Source: Edited based on MNB data

\footnotetext{
${ }^{3}$ This is the so-called fiscal devaluation.
} 


\subsection{Transformation of the taxes on labour}

The most significant step in cutting the taxes on labour was the introduction of the flat-rate personal income tax regime, which reduced the single rate to below the former lowest rate. The elimination of progressivity in several stages (with a complete phase-out of tax credits and "super-grossing") 4 acknowledged and encouraged additional work and performance, i.e. it raised the effective labour supply of those already in the labour market (affecting the elasticity of labour supply at the intensive margin as well). It also reduced the willingness to conceal income on the part of both employees and employers.

One key targeted programme which strongly supported employment was the Job Protection Action Plan (JPAP), which bolstered the demand side of the labour market from 2013. The targeted employers' contribution allowances introduced with the JPAP provide significant support to vulnerable groups in the labour market (those under 25 or over 55 , mothers returning from maternity leave, the unskilled, the long-term unemployed and agricultural labourers). For the most targeted groups, the programme waived the full amount of the social contribution tax up to the first HUF 100,000 of monthly income, and half of it in the other groups. Employment increased overall but especially in the affected groups, by as much as 40 per cent since the introduction of the programme, and 900,000 workers in total benefit from the framework of allowances.

The introduction of the family tax base allowance (FTBA) is mainly a family policy measure for tackling long-term demographic challenges, but by nature it also helps to increase the labour supply. This is because the benefit paid for child(ren) is not universal, as it is conditional on the beneficiary parent having a reported, legal income tax base. Linking benefits to employment encourages active labour market participation and the reporting of undeclared income.

In the Mediterranean countries, the highly progressive structure of personal income tax was not transformed as in Hungary. Similar to Hungary, the Mediterranean countries also used a multi-rate, progressive personal income tax regime before the crisis: Greece had 3 brackets, Italy had 5, Portugal had 7, and Spain had 4. While the progressive nature of the Hungarian income tax regime was eliminated after

\footnotetext{
${ }^{4}$ Tax credits were universal tax allowances reducing personal income tax. The gradual phasing out of this allowance substantially raised the marginal tax wedge, which rose to over 60 per cent above the average wage in 2010, while the marginal tax rate was almost 70 per cent due to the reduction of tax credits to zero and the introduction of the upper bracket of personal income tax. The system of tax credits was completely eliminated in 2012, which contributed to the simplification of the personal income tax regime and the cutting of the marginal tax rate.

Super-grossing was a "hidden" form of raising the taxes on labour, because, instead of the income tax rates, the tax base was raised through administrative measures. The system expanded the personal income tax base by 27 per cent, amounting to the same percentage as employers' social contributions in 2010, raising the average burden at all income levels uniformly. Super-grossing was introduced in 1 January 2010, and it was completely phased out by 2013 in two stages, contributing to the lowering of the taxes on labour.
} 
2010 and replaced with a flat-rate system fostering more proportional public burden sharing, Mediterranean countries retained the multi-rate, progressive personal income tax regime. After the crisis, Greece started using a system with 10 brackets, with Italy having 6, Portugal 7 and Spain 5 brackets, mainly on account of the introduction of special taxes. The amendments increased not only the progressivity and complexity of the system, but also the taxes on labour (Table 2).

\section{Table 2}

Personal income tax regimes in Hungary and the Mediterranean countries before the crisis (in 2007) and afterwards

\begin{tabular}{l|c|c|c} 
& $\begin{array}{c}\text { Number of personal } \\
\text { income tax rates and } \\
\text { surtaxes }\end{array}$ & PIT rates before the crisis & $\begin{array}{c}\text { PIT rates after the } \\
\text { measures }\end{array}$ \\
\hline Hungary & $2+1$ rates $->$ flat rate & $18 \%$ and $36 \%+4 \%$ & $15 \%$ \\
\hline Greece & 3 rates $>4+6$ rates & $29 \%-40 \%$ & $22 \%-45 \%+10 \%$ \\
\hline Italy & 5 rates $>5+1$ rates & $23 \%-43 \%$ & $23 \%-43 \%+3 \%$ \\
\hline Portugal & 7 rates $>5+2$ rates & $10.5 \%-42 \%$ & $14.5 \%-48 \%+5 \%$ \\
\hline Spain & 4 rates $->5$ rates & $24 \%-43 \%$ & $19 \%-45 \%$ \\
\hline
\end{tabular}

Note: The + " $x$ " percentages in the table show the special PITs. The special PITs marked after the measures show the highest possible values.

Source: Edited based on OECD (2017) data

As a result of the Hungarian Government's measures reducing taxes on labour, the marginal tax wedge (the tax burden on a unit of additional income) was lowered considerably after the crisis. By contrast, the tax rate on additional income stagnated or rose in the Mediterranean countries (Figure 5). 


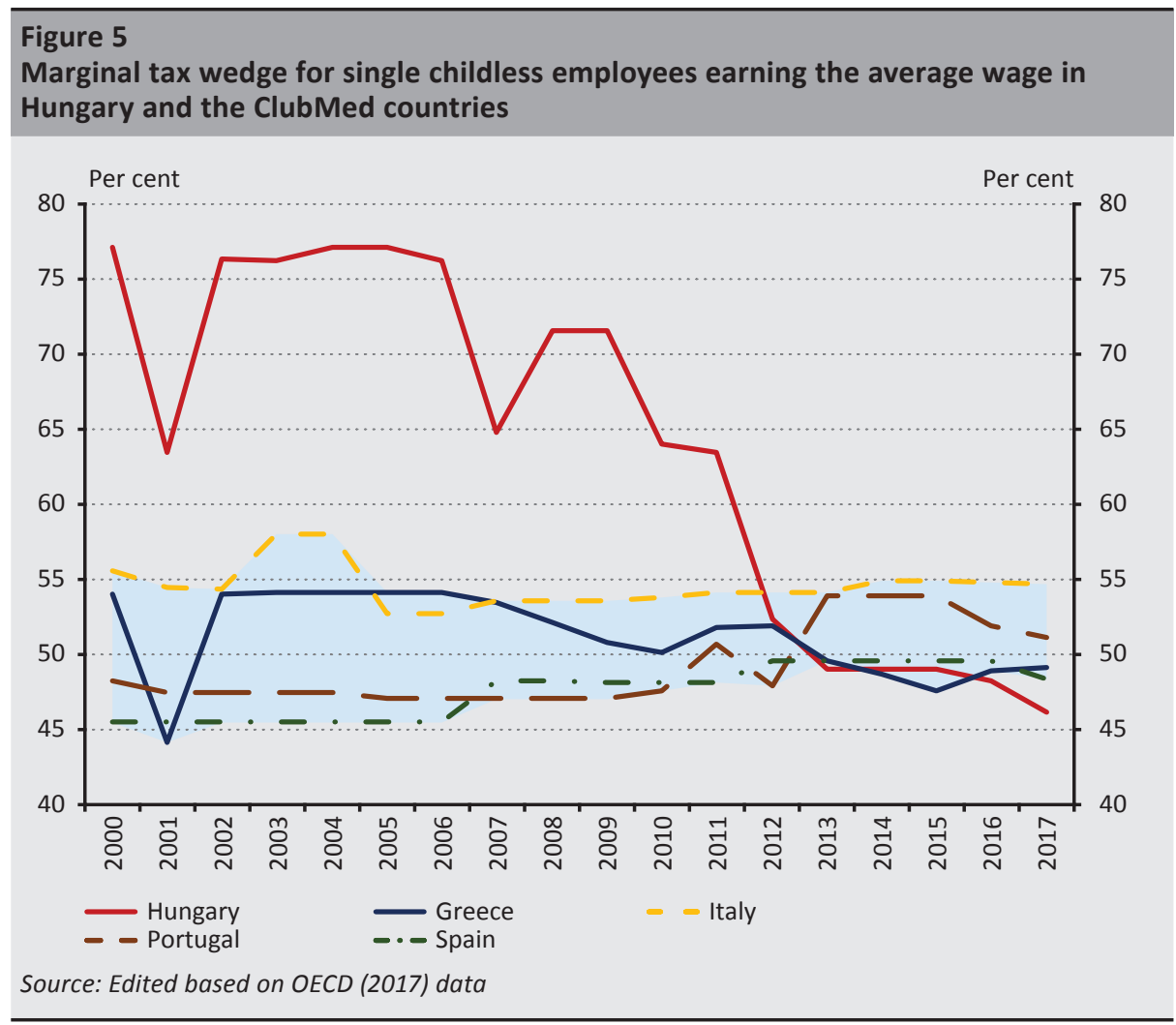

The reduction in the personal income tax (PIT) after 2010 can also be clearly seen in the transformation of the tax structure. Before 2010, PIT revenues in Hungary amounted to around 18-19 per cent of all tax revenues, which puts them in the middle of the range of the Mediterranean countries. However, by 2011, the Hungarian figure had dropped to roughly 13 per cent and by 2016 it had fallen to around 12 per cent, making the share of Hungarian PIT revenues the lowest. By contrast, the PIT revenues of Mediterranean countries moved in the opposite direction, having stagnated or risen in the crisis. Among the countries under review, Italy relies especially heavily on personal income tax for financing the budget (Figure 6). 


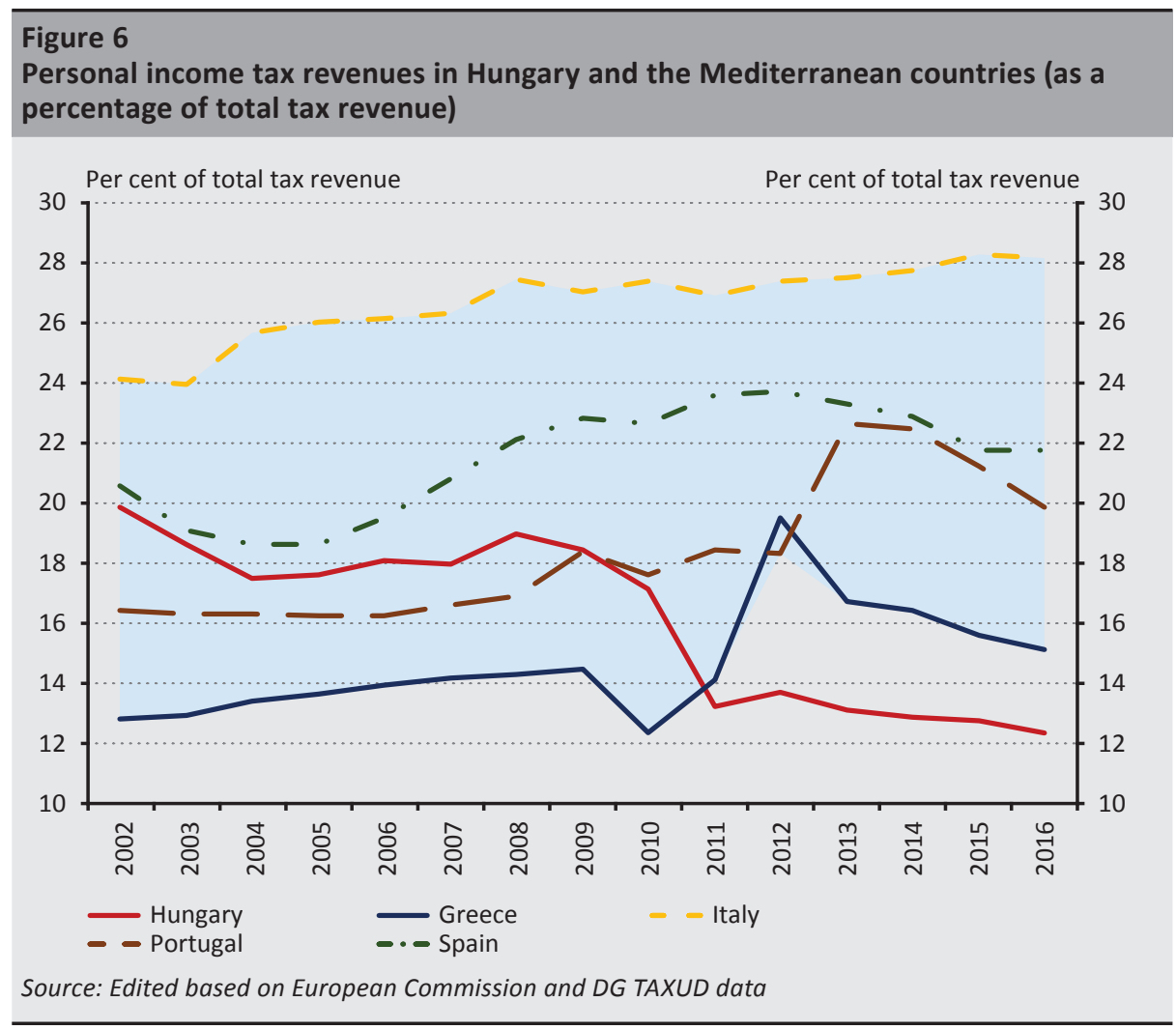

\subsection{Corporate taxes in Hungary and the Mediterranean countries}

Hungarian economic policy also made significant steps in fostering employment and job creation as well as increasing corporate profitability and capital accumulation by reducing taxes on the country's micro, small and medium-sized enterprises. The special support provided to the SME sector is warranted, among other things, by the fact that two-third of Hungarian workers are employed in this sector.

In 2010, the Government already substantially expanded the group of SMEs eligible for a preferential corporate tax rate. In the second half of 2010 the eligibility criterion for the 10 per cent preferential tax rate was increased from HUF 50 million to HUF 500 million in revenues (those above this limit were taxed at a rate of 19 per cent), which considerably expanded the group of firms paying the low corporate tax rate. In 2017, the corporate tax rate was reduced uniformly to 9 per cent, making it the lowest corporate tax in the EU. While the 2010 measure mainly provided a substantial tax relief to micro, small and medium-sized enterprises, the 2017 tax cut 
principally supports the ability to raise capital and corporations' competitiveness (Mosberger 2017).

Just as in the case of the personal income tax, the Mediterranean countries also missed the opportunity to significantly lower corporate taxes during the crisis (Figure 7). In Portugal, the average pre-crisis tax rate of 26.5 per cent had risen to around 30 per cent by the end of the crisis. In the same period in Greece, the corporate tax was raised from 25 to 29 per cent. In the other two Mediterranean countries under review, Spain, and Italy, the corporate tax rate dropped somewhat, but still remained high ( 25 per cent in Spain and 27.8 per cent in Italy).

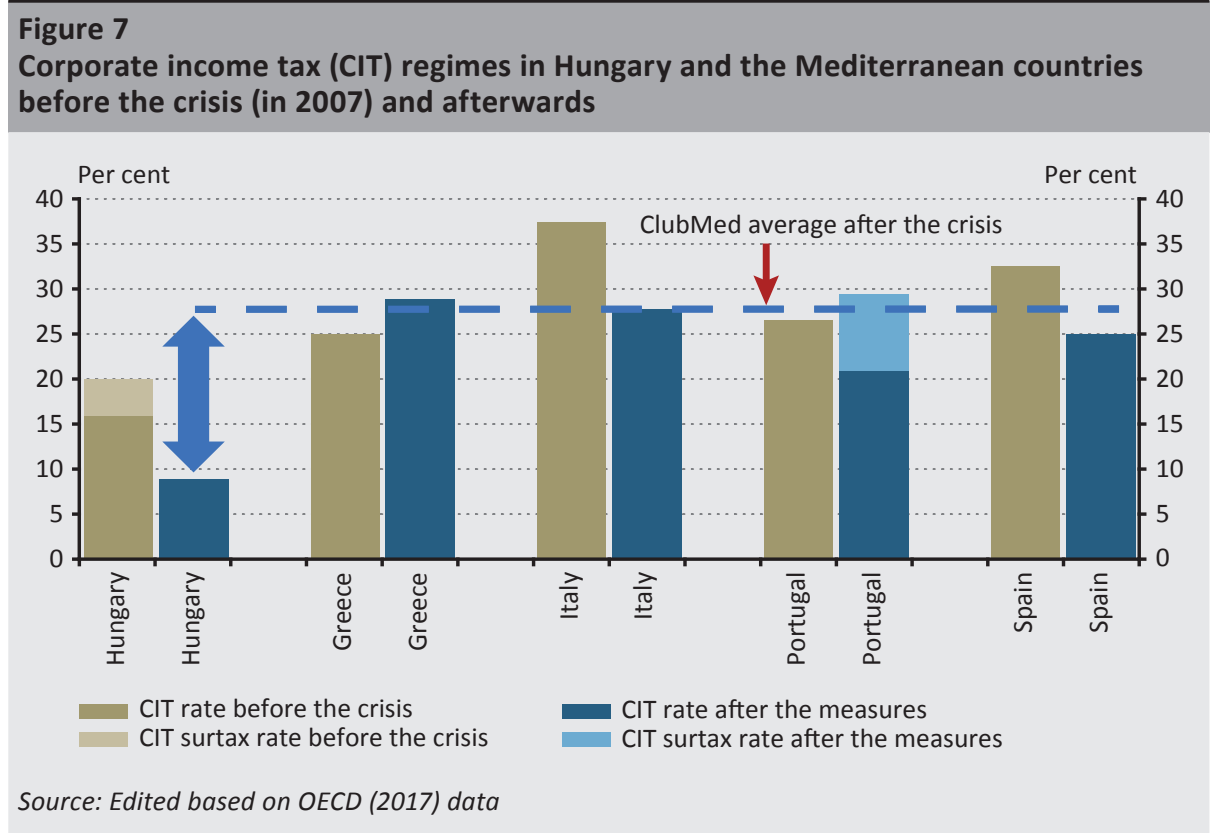

The 2013 introduction of two important, targeted forms of taxation, the small taxpayers' itemised lump sum tax (KATA) and the small enterprise tax (KIVA) further reduced and simplified the tax burden on the Hungarian SME sector's capital income. These targeted small enterprise taxes have become more and more popular, since with these taxpayers can pay taxes in a simplified manner with less administration and lower rates, as they replace several other reporting and payment obligations at the same time. The small taxpayers' itemised lump sum tax is especially simple, as it offers a fixed-rate tax to the smallest companies (HUF 50,000 per month up to an annual income of HUF 12 million when the taxpayer works full time). By 
paying the KATA, taxpayers are exempt from corporate personal income tax, the corporate tax, the dividend tax or lump sum tax, the personal income tax, the personal contributions, the healthcare contribution, the social contribution tax as well as the vocational training contribution, i.e. the administrative burden is significantly reduced. The other new tax type, the so-called small enterprise tax was designed for slightly larger companies, and, with its current 13 per cent rate instead of the 16 per cent upon introduction, it replaces three traditional taxes: the corporate tax, the employers' social contribution (social contribution tax) and the vocational training contribution.

Thanks to the measures, capital taxes were lowered in Hungary, leaving more income for businesses to invest and increase their headcount. Both before and after the global crisis, the share of capital taxes relative to GDP was lower in Hungary than in the Mediterranean countries. In 2010, taxes on capital income were lowered in Hungary, while Mediterranean countries' capital taxes relative to GDP gradually increased (Figure 8).

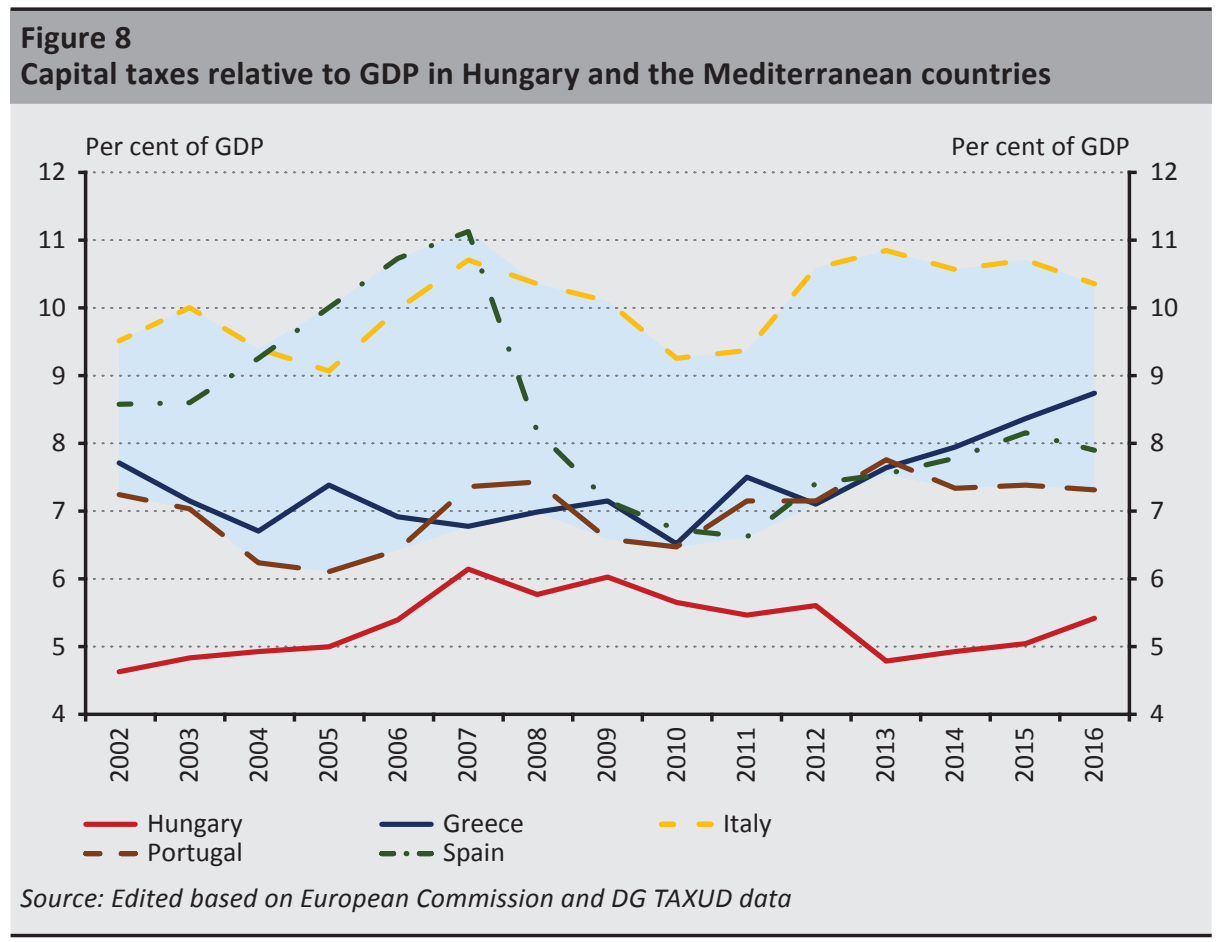




\subsection{Consumption taxes and sectoral taxes for achieving fiscal balance}

Hungary required additional budgetary resources to finance the measures fostering employment and growth, as the first few years of reforms typically entail lower budgetary benefits than costs. There were three possible options for compensating for the lost budgetary revenues:

- introduction of traditional austerity measures;

- high deficit, growing external indebtedness;

- increasing consumption taxes and using alternative, innovative tools (sectoral taxes).

Running a high deficit or introducing austerity measures go against the objectives of the economic policy pursued after 2010, aimed at improving economic balance and stimulating the economy. Therefore, the additional space for fiscal manoeuvre was created by raising consumption taxes and introducing sectoral taxes. Consumption taxes distort economic actors' savings and investment decisions to a lesser extent, and they have an adequately broad tax base, as they also involve into tax paying those who are not formally employed in the labour market (European Commission 2011). The use of sectoral taxes was warranted because well capitalised sectors with lower effective tax rates (banking sector, energy sector, retail sector) were much more resilient than households and thus better fit to bear the additional tax burden. Lowering households' disposable income would have been counterproductive in the crisis years due to the high fiscal multiplier, as was shown by the example of the Mediterranean countries.

The increase in consumption taxes significantly shifted the Hungarian tax structure towards consumption taxes (Figure 9). The most important step was increasing the VAT rate from 25 to 27 per cent. The growing proportion of consumption taxes was also influenced by the fact that the sectoral taxes has been largely phased out from 2013 , to be replaced by new consumption and turnover-type taxes (e.g. insurance tax, telecommunications tax, financial transaction tax)..$^{5}$

${ }^{5}$ Eurostat lists the special taxes, such as the financial transaction tax, the advertising tax, the accident tax, the insurance tax, the telecommunications tax and the public health product tax, among consumption taxes. 


\section{Figure 9 \\ Consumption tax revenues in Hungary and the Mediterranean countries (as a percentage of total tax revenue)}

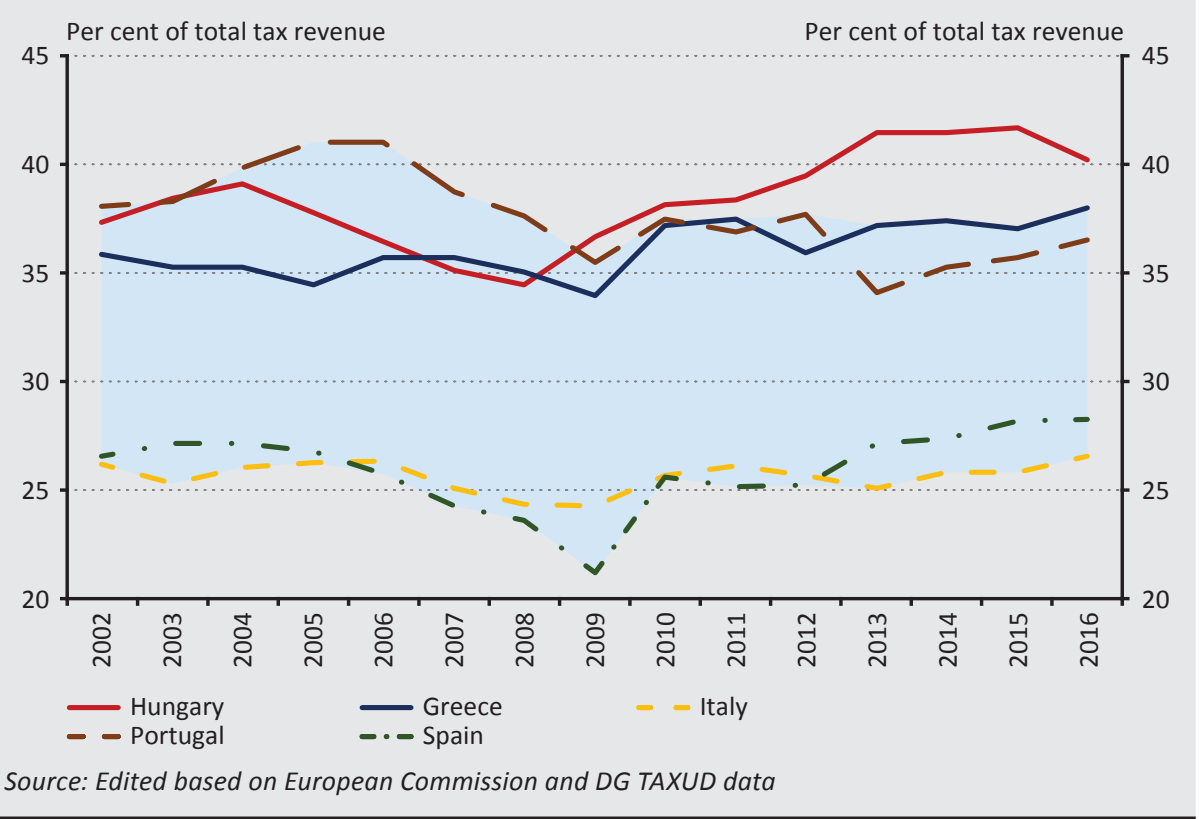

Tax revenues were increased without raising the tax rates, by the effective steps taken to reduce tax evasion. The most important measure against shadow economy was the establishment of an online link between the retail sector's cash registers and the tax authority in several stages. As a result, there were more than 200,000 controlled cash registers in operation by 2016 (Szalai - Kolozsi 2016). Another factor that contributed to combating the shadow economy was the introduction of the Electronic Trade and Transport Control System (EKÁER) ${ }^{6}$ as well as the use of the reverse charge on VAT in several areas. Due to these measures, the Hungarian shadow economy diminished significantly after 2013. According to the European Commission's calculations, the Hungarian VAT gap ${ }^{7}$ dropped from 21 to 14 per cent between 2013 and 2015 (European Commission 2017). Furthermore, estimates about the effective VAT rate calculated as the tax revenues divided by the estimated tax base also show that the shadow economy is shrinking. The effective rate rose by over 2 percentage points between 2013 and 2015 without any change in the VAT rates (Figure 10).

\footnotetext{
${ }^{6}$ The EKÁER is a government infrastructure aimed at reducing the shadow economy in Hungarian transport activities and increasing food safety, which was developed in harmony with the Széll Kálmán Plan, and which started functioning on 1 January 2015. Transport data need to be recorded in a central electronic system before transportation, which strengthens the position of law-abiding market participants, the transparency of the trade in goods and facilitates the identification of tax evaders.

${ }^{7}$ One tool for measuring the shadow economy is the calculation of the VAT gap, which is the difference between the potential and actually collected VAT revenues.
} 


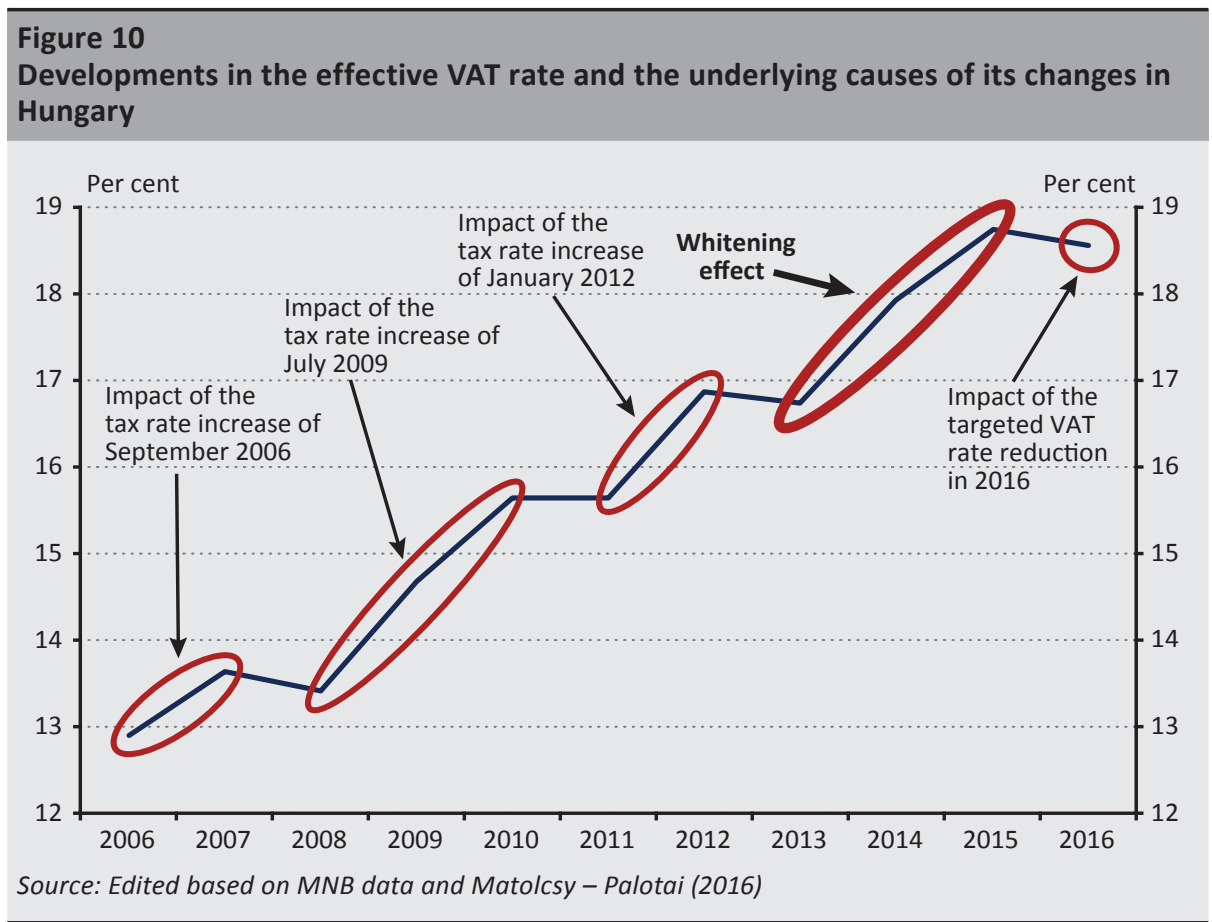

\subsection{Structural reforms versus austerity measures}

Hungary and the Mediterranean countries also chose different paths in terms of transforming budgetary expenditures. The traditional method of stabilising the budget is to cut spending. In a crisis, when fiscal austerity affects the economy especially strongly due to the general lack of demand and funds, such measures point towards deepening the recession. If the demand of the private sector is not strong enough to offset the fall in government demand, the recession continues to deepen. Therefore, expenditure cuts need to be coupled with structural reforms, which result in the more efficient utilisation of expenditures and resources.

Hungary linked the reduction in budgetary spending to competitiveness reforms stimulating the labour market. Before 2010, the unreasonably loose social transfer system resulted in high budgetary expenditures and low labour market participation rates. The targeted reforms of the Széll Kálmán Plans reduced spending and also increased labour market participation. The rules for early retirement were significantly tightened, the eligibility criteria for disability pensions were reviewed, and both the maximum duration and transfer amounts of unemployment benefits were cut. As a result, Hungary managed to substantially lower the number of people receiving early retirement benefits (Figure 11), while the participation rate increased, which increased the labour supply and the number of workers waiting until old-age retirement and contributed to the stabilisation of the budget balance. 


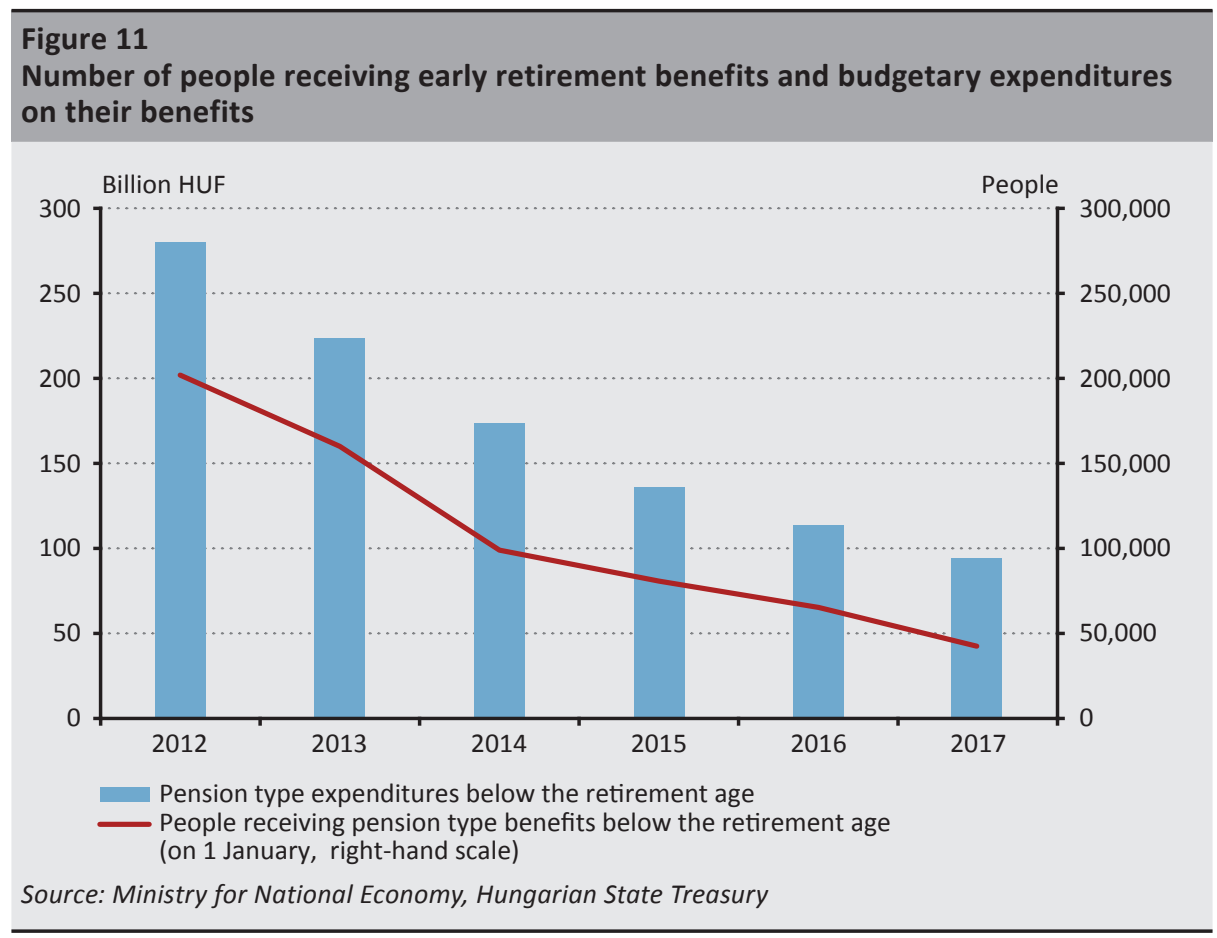

The private pension fund reform not only helped to stabilise the budget, but also eliminated a wasteful, low-efficiency system. The funds invested a large portion of their guaranteed inflows in government securities, which financed the mounting debt exactly because of the contribution revenues foregone in favour of the funds (Banai-Palotai 2018). The sector was characterised by weak competition and high operating costs, which increased the budget deficit by 1-1.5 percentage points every year. The elimination of the compulsory private pension fund membership and the preference of the option of returning to the state system contributed significantly to bringing down the budget deficit to below 3 per cent and placing the government debt on a steadily downward path.

The Government spent a portion of the savings from the structural reforms on expanding and developing the public work programme. Economic policymakers wished to provide "work instead of benefits" even to those who had previously been inactive, creating an opportunity to return to the labour market. The programme is by nature temporary in the sense that it does not aim to tie down labour in this form for a long time: the number of participants has been gradually declining since 2016 . It aims at offering an opportunity to participate on the primary labour market (the share of which has been gradually increasing, as the number of public workers has dropped from around 220,000 to below 160,000 , meanwhile the participation rate jumped while the unemployment rate fell). It is also an effective tool for cushioning the effects of the economy's cyclical fluctuations exerted on the labour market and 
reducing hysteresis. On account of the reforms, participation and employment have increased spectacularly, while the unemployment rate have fallen to among the lowest in the European Union (3.9 per cent) by early 2018.

Instead of targeted reforms, the Mediterranean countries sought to balance the budget through austerity measures, but this entailed huge growth sacrifices. In Portugal in 2011, public sector wages were reduced by 5 per cent on average and pensions were frozen. In 2013, pensions were reduced in a progressive system, and public sector wages declined further (also in a progressive system). Meanwhile, the number of public sector employees dropped by 10 per cent between 2011 and 2014. In Spain, pensions were frozen in 2011. In parallel with this, the number of public sector employees fell by 375,000 between 2011 Q3 and 2013 Q1. In Greece, in addition to the cuts in public sector wages, pensions over EUR 1,000 were reduced in 2011, then the 13th and 14th monthly pensions were completely abolished in 2012. In 2013, 15,000 public sector jobs were terminated. The following year, public sector wages and pensions were frozen for another four years.

All in all, the Mediterranean countries chose the traditional path of fiscal consolidation, while Hungary undertook structural reforms. Although in the first years of the crisis, similar to others in the EU, the ClubMed countries loosened their fiscal policy, this seemed to be unsustainable due to the previously accumulated imbalances, and therefore they were forced to rethink their economic policies after 2010. Based on the recommendations by international organisations, the Mediterranean countries started a major fiscal tightening without domestic reforms, which - similar to the crisis management efforts in Hungary in 2008-2009 - curbed GDP, i.e. deepened the recession, even more than expected.

The Hungarian fiscal turnaround could be, and turned out to be, successful because it stimulated growth and employment, while also broadening the tax base. One of the cornerstones of the domestic reforms was shifting the focus of tax centralisation from the taxes on labour towards consumption taxes. The goal was to vitalise both the supply and the demand side of the labour market and to combat the shadow economy. In addition to supporting employment and families, the Government also fostered the profitability of the SME sector by reducing the corporate tax in several steps as well as by developing simplified, preferential small enterprise taxes. The achievement of fiscal balance was aided by higher consumption taxes and the larger tax burden (sector taxes) on the sectors with greater social resilience (banking, energy, telecommunication and retail). Fiscal balance was supported by further measures aimed at reducing the shadow economy (e.g. the introduction of online cash registers and the EKÁER) from the revenue side, and by the structural reforms included the rationalisation of early retirement and disability retirement (Széll Kálmán Plans) from the expenditure side. 


\section{Different monetary policies in Hungary and the euro area}

Hungary and the Mediterranean region of the euro area faced the crisis with strikingly different monetary policy frameworks, which to a great degree determined the possibility of consistency between fiscal and monetary policy, which became key for crisis management. As the fiscal rules represented a strict constraint on stimulating the economy, the role of monetary policy has gained in relative importance in recent years. While the single monetary policy of euro area countries is determined by the European Central Bank, the Magyar Nemzeti Bank can conduct autonomous and, when necessary, effectively targeted monetary policy in Hungary. The fixed exchange rate regime required autonomous central bank objectives and the free choice of tools to be given up, which narrowed economic policymakers' room for manoeuvre. Moreover, these economies generated no inflation through their fiscal policies either which without the appropriate easing of monetary conditions led to the emergence of a strongly disinflationary and then deflationary environment in this region, with the risk of a vicious deflationary spiral (Figure 12).

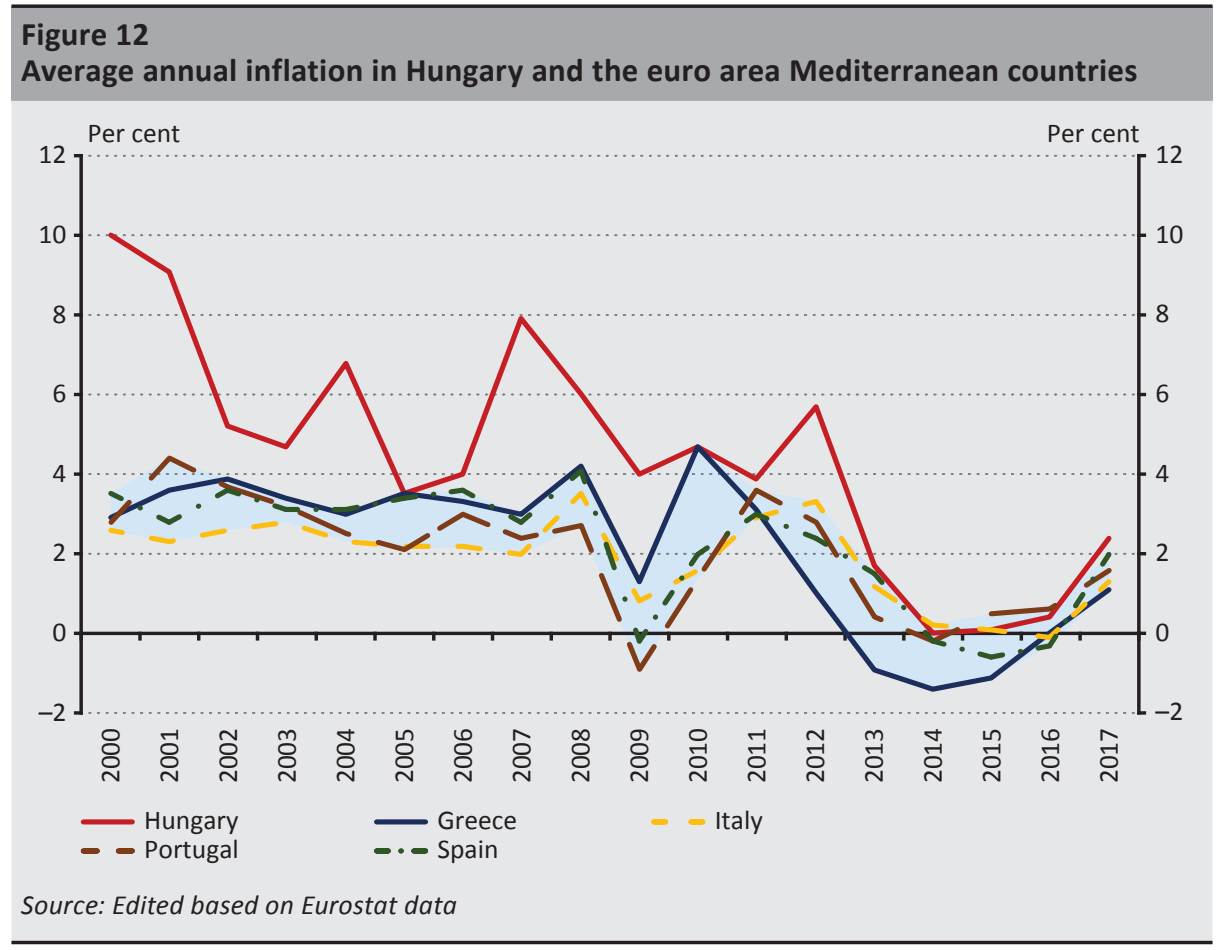


The autonomous monetary policy enabled Hungary to develop a constructive consistency between fiscal policy and central bank policy. However, this could only be achieved in 2013, when the new central bank leaders took office. From 2013, the MNB started introducing innovative programmes fostering stability and economic growth, and therefore Hungary's crisis management could be more effective than the Mediterranean model. The MNB has supported the total economy through the interest rate cutting cycles, the Funding for Growth Scheme (FGS) stimulating corporate lending and investments, the Growth Supporting Programme, the SelfFinancing Programme reducing the macro-financial vulnerability of the country as well as the forint conversion of household FX loans conducted in cooperation with the Government.

\subsection{Monetary policy turnaround and targeted measures in Hungary}

Budgetary stabilisation and the independent monetary policy paved the way for a monetary policy turnaround in Hungary after 2013, which was based on the significant reduction of the policy rate and targeted measures.

The lower policy rate reduced the interest burden in all sectors of the economy while also supporting investments and consumption. Low inflation and the improving risk perception of the economy after the fiscal consolidation provided ample room for manoeuvre for the Magyar Nemzeti Bank to create steadily favourable monetary conditions actively supporting growth. The first and traditional tool for this was the prudent and gradual decrease of the central bank base rate from 7 per cent to the historic low of 0.9 per cent between 2012 (i.e. from the interest rate cuts launched with the support of the then new external members of the MNB Monetary Council) and 2016 (Figure 13). Government securities yields followed the development of the base rate in the context of low inflation, the favourable international money market environment and Hungary's improving risk perception, which showed that investors also considered monetary policy sound and credible. The falling yields considerably reduced the government's interest expenses. Total savings have amounted to 4.5 per cent of GDP since 2013 (HUF 1,600 billion). 


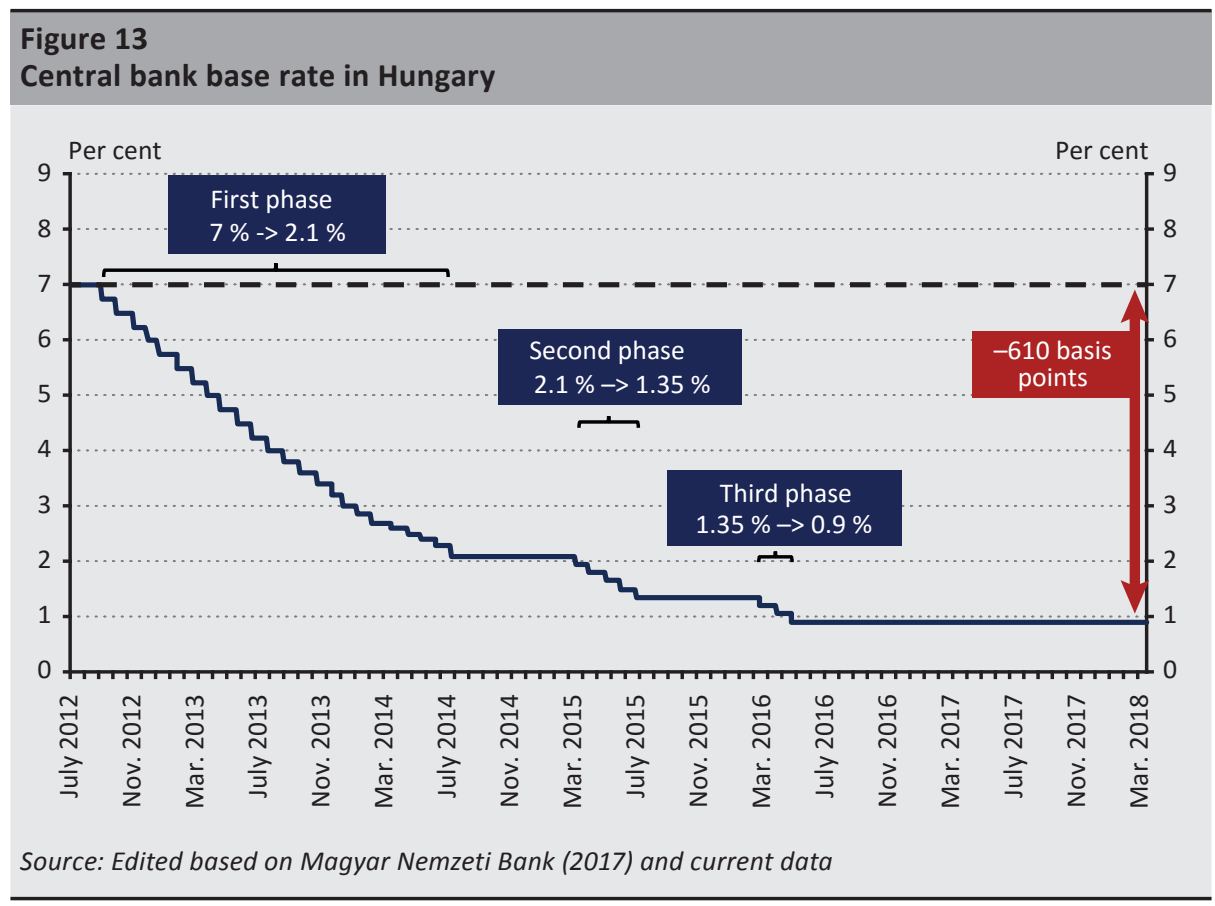

The Funding for Growth Scheme and later the Growth Supporting Programme were targeted tools supporting the SME sector that helped avoid the risk of a creditless recovery. Similar to some foreign central banks, in addition to the general, traditional tools, the Magyar Nemzeti Bank used targeted, unconventional measures to effectively address the unprecedented money market and real economy crisis. Such measures included the MNB's Funding for Growth Scheme announced in the spring of 2013, which sought to alleviate commercial banks' insufficient SME lending. This was necessary because there was a real danger of the credit market (which had contracted by around 6 per cent annually since mid-2009) freezing completely, which would have entailed a persistent growth sacrifice and also undermined potential growth. To address this issue, the MNB offered refinancing loans to the commercial bank sector at 0 per cent, which had to be lent to the SME sector with a premium of up to 2.5 per cent (for fixed capital formation, working capital acquisition, FX loan refinancing and prefinancing EU funds). Within the framework of the programme, around 40,000 SMEs obtained preferential loans amounting to HUF 2,800 billion (8 per cent of GDP) in total. Thanks to the success of the FGS and the Growth Supporting Programme (GSP) introduced in 2016, which aimed to gradually phase out the FGS and smoothly shift corporate lending to market financing, the contraction in credit was reversed, and by the end of 2016, SME lending had started increasing dynamically (Figure 14). 
According to Magyar Nemzeti Bank (2016) estimates, the rate-cutting cycles and the central bank programmes fostering lending activity contributed to around half of the economic growth in recent years, directly and indirectly, and they also exerted a positive impact on potential growth.

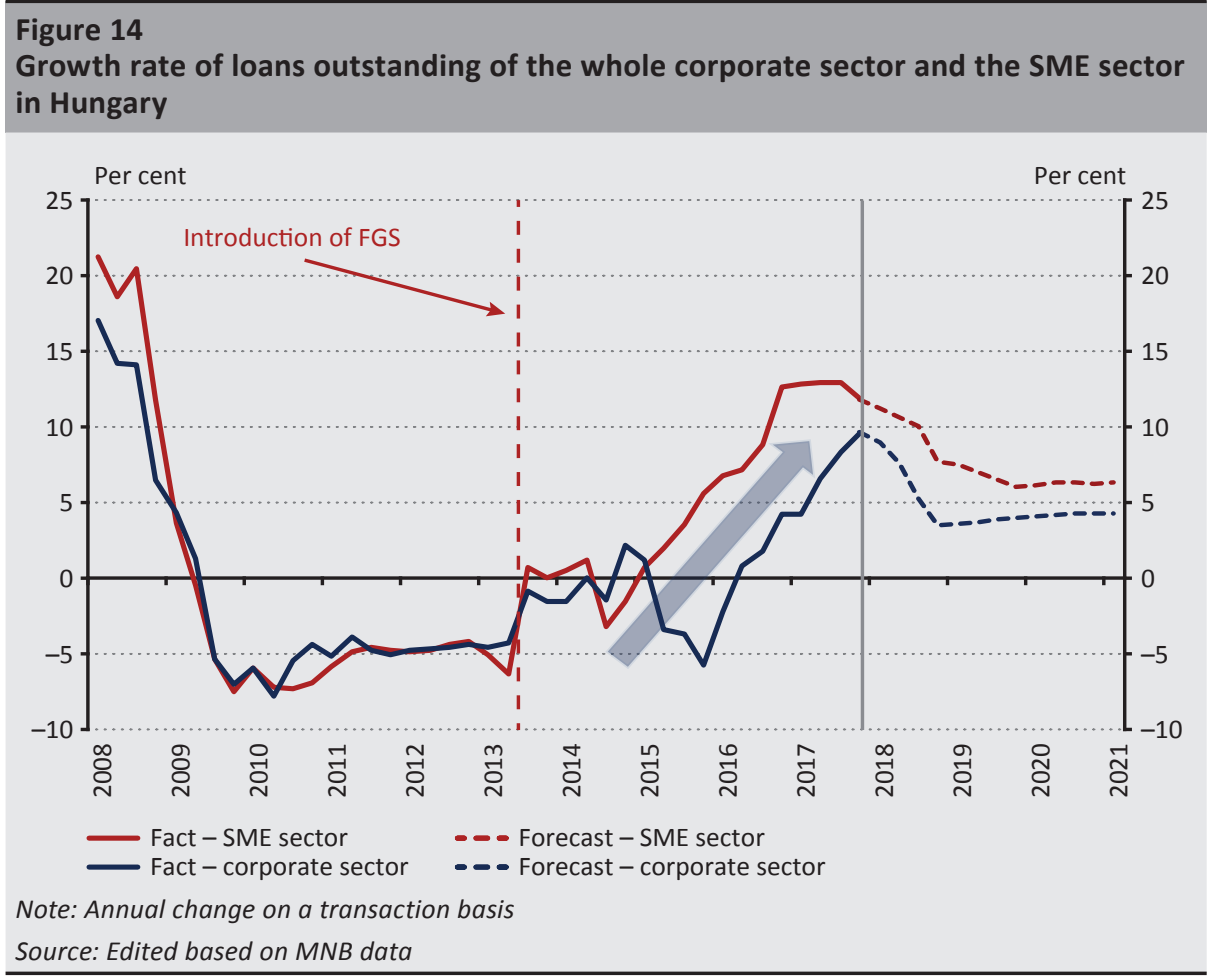

The Magyar Nemzeti Bank's Self-Financing Programme aimed to reduce the external vulnerability of the economy. The Self-Financing Programme was introduced by the central bank in mid-2014 and was then expanded in 2015 and 2016 in several stages. The primary goal of the programme was to reduce external vulnerability and improve the risk perception of the total economy, and to mitigate the central bank's FX reserve requirements by lowering external financing and expanding the domestic investor base. Therefore, the MNB encouraged commercial banks to keep their liquid assets in securities rather than in the central bank's sterilisation instrument. During the programme, the central bank policy instrument was transformed from a two-week bond into a three-month deposit, which considerably reduced its liquidity. Furthermore, the conditional central bank interest rate swap (IRS) was temporarily introduced to mitigate the interest rate risk of commercial banks arising from purchasing long-term, fixed-rate securities (Magyar Nemzeti Bank 2015). 
The programme contributed substantially to enhancing the financing structure of government debt as well as to lower exchange rate exposure via a significant reduction in the share of foreign ownership and the foreign currency ratio in debt. After the extremely high figures at the end of 2011 , both ratios are currently at historic lows (Figure 15).

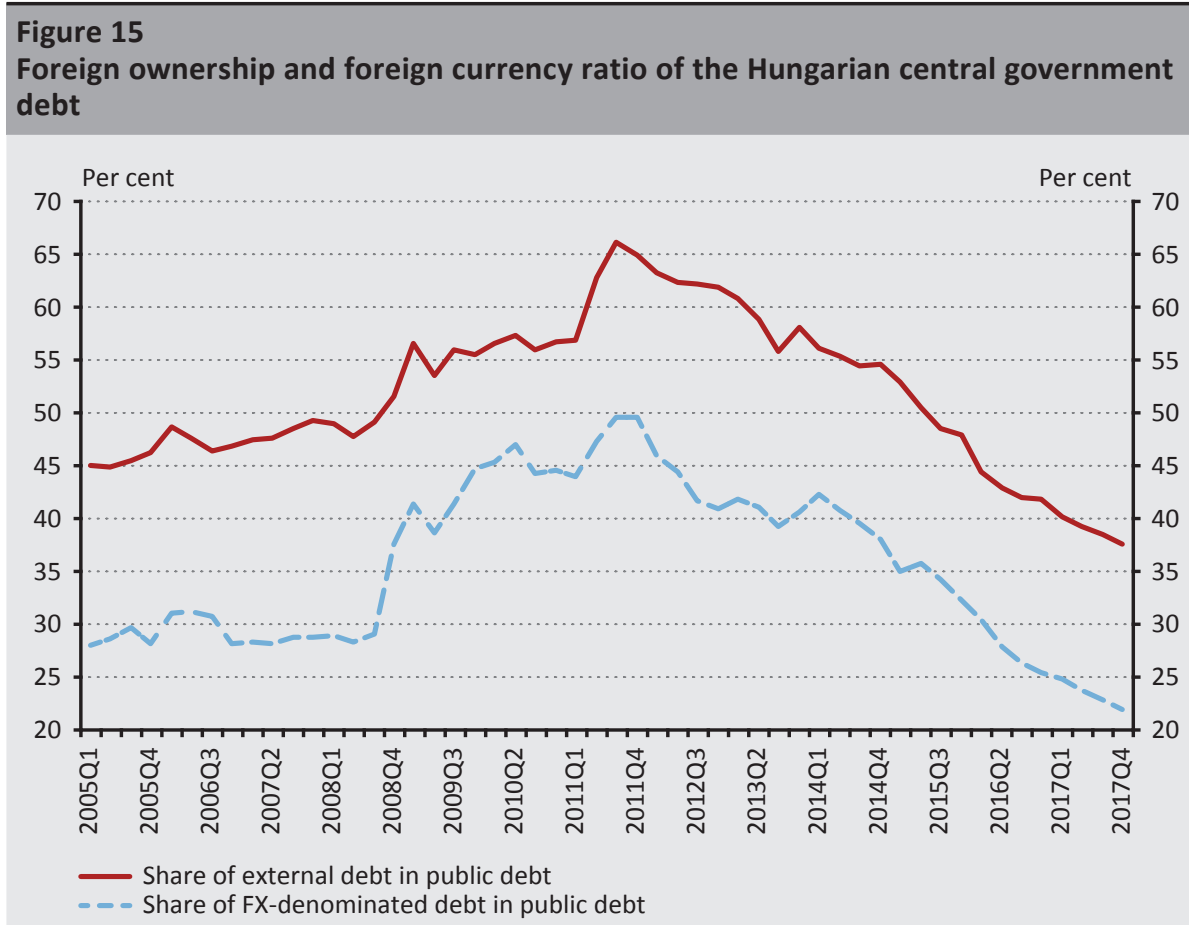

Source: MNB, Government Debt Management Agency

The phase-out of households' FX mortgages in cooperation with the Government and the banking sector saved the country from an economic and social catastrophe. As a result of the widespread, large-scale FX-denominated lending from 2003, by the time the 2008 global crisis hit, a large portion of the private sector had become indebted in foreign currency, which entailed a huge systemic risk even by international standards, due to the significant exchange rate exposure (Figure 16). This is because on account of the considerable weakening of the forint due to the crisis, the monthly payments of the debtors increased dramatically, making housing conditions uncertain for hundreds of thousands of people. In parallel with this, the rising payments also stymied aggregate demand, as they reduced the disposable income and consumption of debtors and drastically increased the ratio of nonperforming loans (NPLs) (4-6-fold) in the banking sector, which jeopardised the 
stability of the financial system. Meanwhile, the widespread FX lending impaired the monetary policy transmission mechanism, as Hungarian monetary policy could not influence the interest rates on the loans denominated in foreign currency. It became crucial for society and for economic policymakers to phase out the FX-denominated loans as soon as possible, but only the Government that came to power in 2010 was determined to go that far.

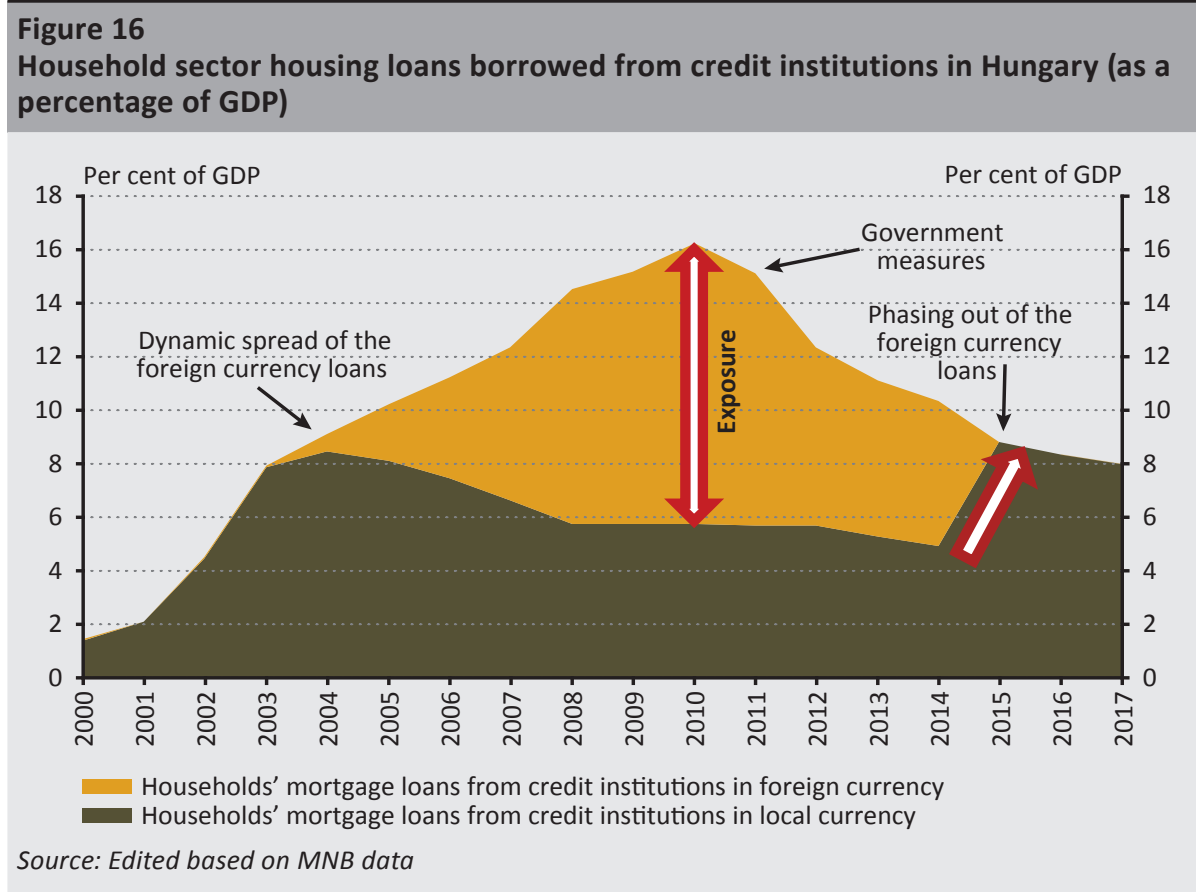

Since 2013, the Magyar Nemzeti Bank has helped with all its available means in settling the matter of households' FX loans. Before the Supreme Court's (Curia) uniformity decision in mid-2014, the MNB played a proactive role in the negotiations between the Government and the Banking Association, and then contributed significantly to the successful forint conversion of household FX loans by providing the necessary liquidity (EUR 9 billion) to the banking sector (Kolozsi et al. 2015). To ensure the success of forint conversion and prevent money market speculation, the conversion rate had to be fixed in advance and without informing market actors, which required close cooperation from the three players, the Government, the Central Bank and the Banking Association (Nagy 2015). FX loans started to be converted in the autumn of 2014 with the announcement of the FX tenders linked to the phase-out of household mortgages, and they were followed by personal and car loans in 2015, therefore by the end of 2015 Hungarian households basically had no FX loans on their balance sheets. The average monthly instalments on the previously Swiss franc-denominated housing loans plummeted by 25 per cent. 
The importance of these measures was later underlined by the fact that all this was achieved before the Swiss National Bank discontinued the use of its exchange rate floor against the euro, after to which the appreciation of the Swiss franc would have had unpredictable consequences.

\subsection{The European Central Bank's crisis management was insufficient for the ClubMed countries}

The single monetary policy of the euro area practically gives no possibility to apply targeted central bank measures at the national economy level. This would be appropriate if the euro area were an optimum currency area, but the crisis has shown that this is not the case. The conditions for joining the euro area, i.e. the socalled Maastricht criteria, focus entirely on the financial stability of the economy, or more precisely on certain segments of that (inflation, yields, exchange rate stability, general government). However, we believe that the successful functioning of the currency area has further conditions. Nagy and Virág (2017) summarised these as follows: (i) real convergence, (ii) harmonisation of business cycles, (iii) similar levels of competitiveness, (iv) adequate financial sector, (v) available countercyclical policies. However, the euro area is characterised by considerable differences in these factors. Peripheral countries typically faced larger deflationary risks and higher unemployment rates. The economic situation and structure of northern and southern countries was different even at the time of their euro adoption and the crisis only amplified the differences. The euro area does not allow nominal exchange rate adjustment, but has not ruled out the possibility of huge real exchange rate differences emerging among its members. One of the main drivers behind the emergence of real exchange rate differences was divergent wage dynamics (Sapir 2016).

The European Central Bank only belatedly used unconventional instruments, which deepened the crisis in several Member States. The ECB responded to the crisis with rapid interest rate cuts, but it used other monetary policy instruments only belatedly (Matolcsy 2015), which kept monetary conditions relatively tight ${ }^{8}$. While managing the sovereign debt crisis, the ECB's measures aimed to reduce bond market spreads and restore the transmission mechanism to avoid defaults in peripheral countries. The ECB launched the Securities Markets Programme (SMP) in 2010, seeking to lower the excessive spreads by purchasing the government bonds from Mediterranean countries. Due to its size, the programme was only able to halt the rise in spreads and was unable to achieve a permanent drop in yields. The persistence of high yields in peripheral countries contributed to the unsustainably high levels of government debt and that these economies required external financing. The bonds purchased in the course of the programme amounted to

\footnotetext{
${ }^{8}$ This was exacerbated by the fact that the ECB attempted to launch the tightening cycle too early, in 2011.
} 
EUR 217 billion, which proved to be insufficient with respect to the affected Italian, Spanish, Portuguese, Greek and Irish papers in the long run (Lehmann Mátrai - Pulai 2013). The programme was not transparent, since the ECB did not communicate its purchases and their individual amounts, only the total holdings, and therefore no information could be obtained on the purchased amounts by country. The difference in market reactions is clearly shown by the fact that after President Mario Draghi's "Whatever it takes" speech and the announcement of the Outright Monetary Transactions (OMT) programme, the Mediterranean country yields started rapidly converging to core euro area yields. The two instruments differed in their amount, as one of the main messages of the OMT was that there was no upper limit on the planned purchases. The ECB repeatedly mentioned in its communication that these countries needed structural reforms and an overhaul of their fiscal policy. Yet one might still wonder whether it was worth waiting with an OMT-type measure until 2012. Demertzis and Wolff (2016) argue that the size of the first asset purchases relative to GDP was miscalculated, and the ECB only corrected this in 2016. ${ }^{9}$

All in all, due to the deepening debt crisis and the restrained monetary policy, not even the main objective, i.e. the inflation target, could be achieved in the euro area (Demertzis - Wolff 2016). The gradually introduced and expanded unconventional instruments helped stimulate the economy but their effect proved to be insufficient.

\section{Success of the Hungarian reforms in view of Mediterranean countries' experiences}

The different crisis management tools led to different results in the Mediterranean region and Hungary. ${ }^{10}$ In contrast to the traditional crisis management logic, Hungary managed to stabilise the budget and restore economic growth sooner than Mediterranean countries. We believe that this was mainly due to the success of the employment policy turnaround, which was also heavily influenced by the economic policies supporting corporate investments. In contrast to the Hungarian measures, the adjustments in Southern Europe had a drastic effect on employment and also capital accumulation, which exerted a negative impact on both aggregate demand and long-term growth. Between 2007 and 2013, Hungary's investment ratio relative to GDP dropped by less than 3 percentage points (from 24 to 21 per cent), while the same figure in ClubMed countries decreased by over 9 percentage points on average (from 25 to 16 per cent). The indicator was then characterised by stagnation and moderate growth until 2017 in all countries. Only Hungary managed to exceed

\footnotetext{
${ }^{9}$ The comprehensive analysis of the European Central Bank's crisis management is beyond the scope of this paper. For more information on this, see Chapter 4 of Magyar Nemzeti Bank (2017).

10 The figures in this chapter were based on György Matolcsy's presentation at the opening plenary session of the 2017 Annual Congress of Economists of the Hungarian Economic Association (Matolcsy 2017).
} 
the 2010 level by 2017 ( 21.5 per cent), while the Mediterranean countries remain below that with 16.7 per cent on average.

In line with the intentions of Hungarian economic policymakers, the economy practically reached full employment by 2018. The number of people in employment grew by roughly 20 per cent between 2010 and 2017 (from 3.7 million to 4.4 million), with the employment rate rising from 55 to 68 per cent. The Hungarian employment rate showed the second largest improvement in the EU, catching up with the average of not only the EU but also the country's Visegrád peers, and surpassing Mediterranean euro area members. In the case of Mediterranean countries, serious structural problems might be behind the fact that they still have not come close to their pre-crisis position with respect to the employment rate (Figure 17). An even more telling sign is that the Hungarian unemployment rate sank to an unprecedented low, 3.9 per cent, in early 2018. By contrast, in Mediterranean countries the 6-9 per cent characteristic in the pre-crisis period was not achieved by any of the economies (Figure 18).

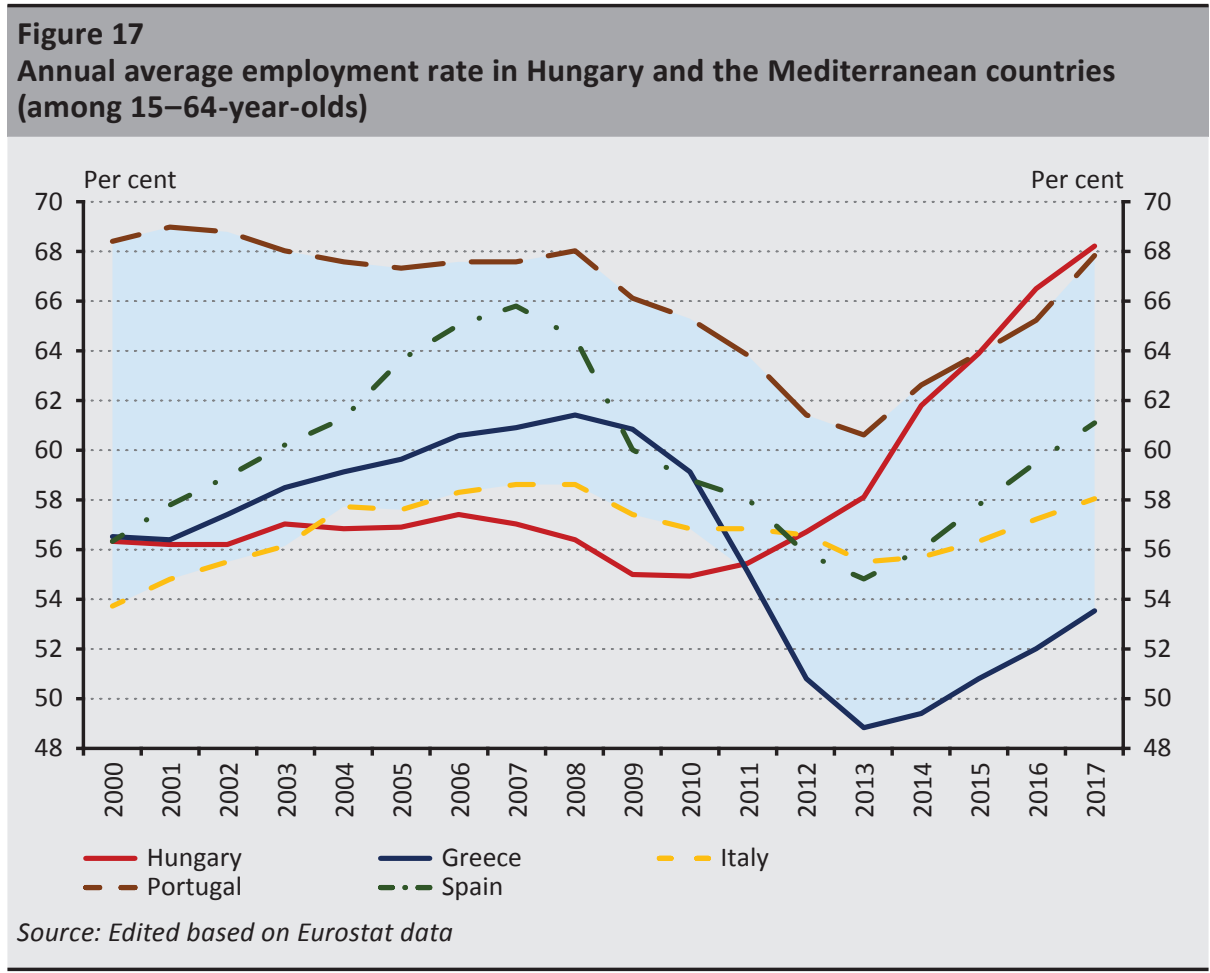




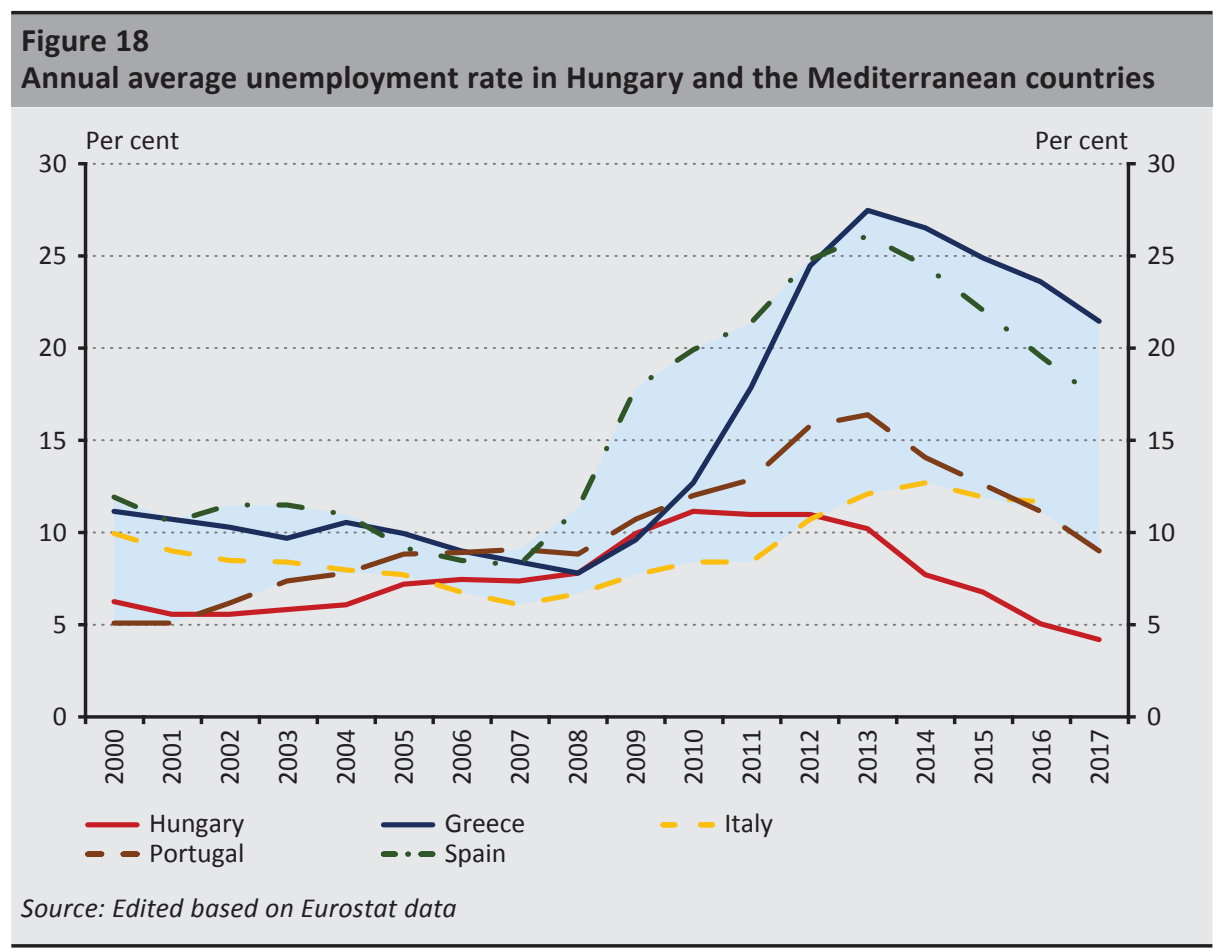

The expansion of employment laid the foundations of economic growth in Hungary, while the Mediterranean countries' GDP still fell short of the pre-crisis level in 2016 (Figure 19). Hungarian GDP expanded by almost 17 per cent between the 2009 recession and 2017, which is 11 per cent higher than the pre-crisis level in 2007. Since 2013, the growth rate of the Hungarian economy has been significantly higher than the EU average, and, in contrast to the pre-crisis period, it is on par with the average growth in the Visegrád region. By contrast, the difficult recovery of the Mediterranean region is illustrated by the fact that with the exception of Spain, the ClubMed countries still have not been able to reach the 2007 level. Greece has suffered a 25 per cent setback in growth that it has not been able to offset since 2013. 


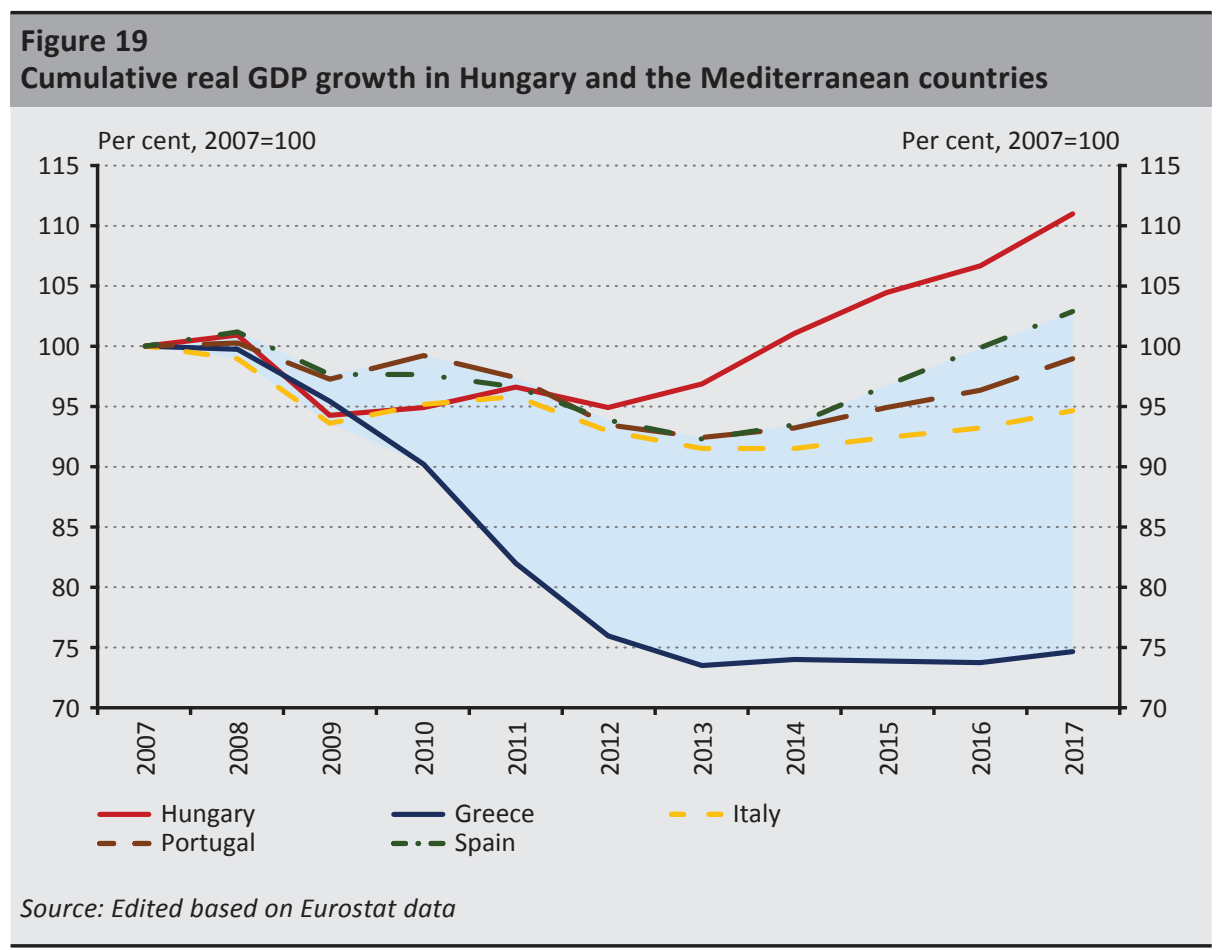

After 2010, Hungary was able to create room for manoeuvre for the implementation of reform steps through the tax reform while ensuring fiscal balance. Since 2011, the Hungarian deficit-to-GDP ratio has been consistently below the European Union's 3 per cent Maastricht criterion. By contrast, most Mediterranean countries were able to meet the EU's deficit criterion only in 2016 (Figure 1). The 2010-2013 tax reform exerted its economic stimulus effect and thus padded budget revenues gradually, therefore tax revenues in Hungary increased by almost 2 per cent of GDP between 2014 and 2016 without raising the tax rates (Palotai 2017).

In Hungary, the previously upward trend in the government debt ratio was halted by the growth-friendly fiscal consolidation from 2011 (Matolcsy - Palotai 2016). The gross debt-to-GDP ratio fell from its historic peak of 80.5 per cent in 2011 to 73.6 per cent by the end of 2017. Hungary achieved the fifth largest debt reduction in the EU between 2010 and 2017 (the debt ratio decreased in 10 countries and increased in all the rest). By contrast, the government debt of Mediterranean euro area countries have been stagnating at the high level seen after the 2008 crisis (Figure 20). 


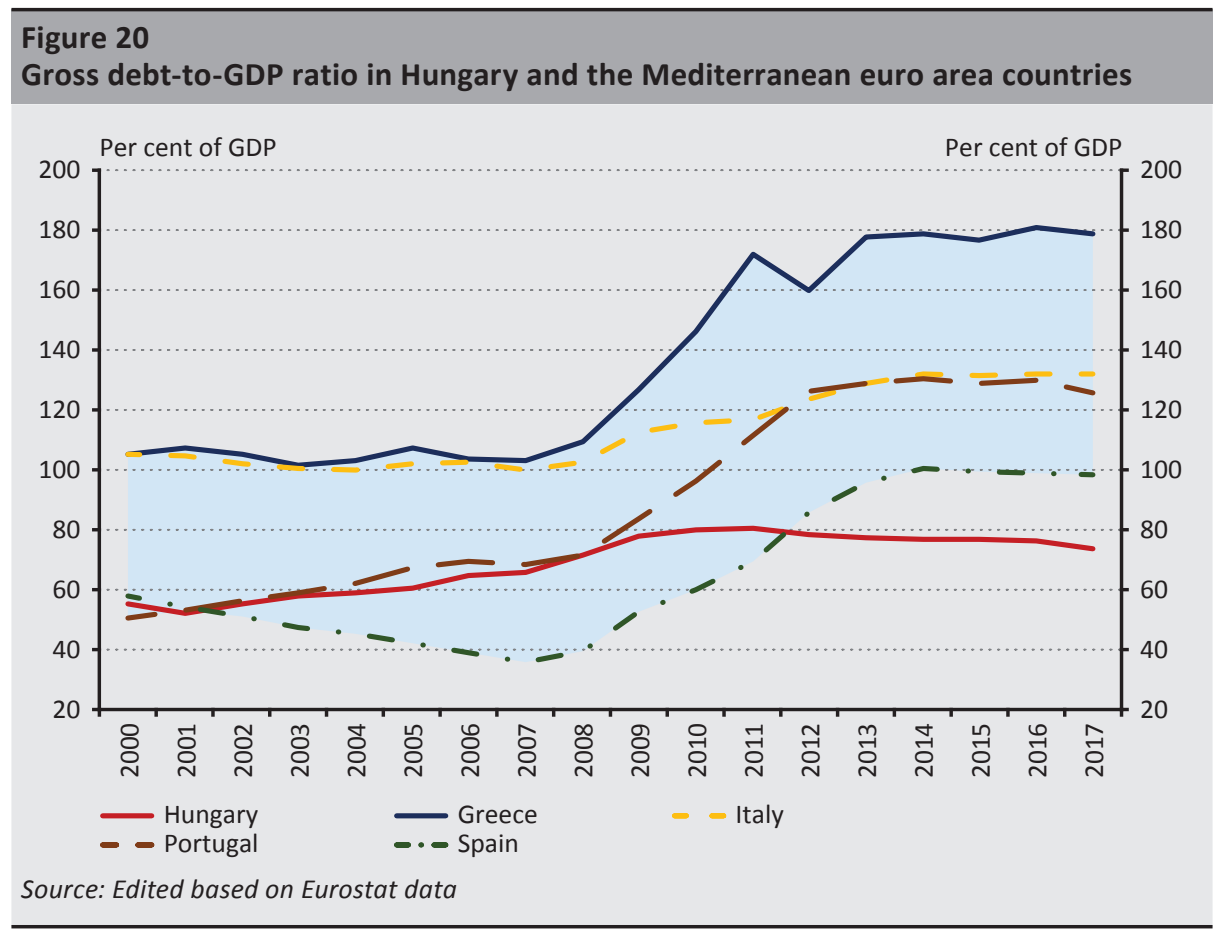

\section{Summary}

The new model in Hungarian economic policy introduced after 2010 which used innovative and targeted tools resulted in an effective crisis management in an international comparison. It has been ten years since the outbreak of the global financial crisis, and thus it is now possible to take stock of the crisis management efforts of Hungary and compare them to the results by other countries.

Despite the similar initial situation, the Mediterranean countries and Hungary chose different ways in almost all aspects of crisis management (Figure 21). The ClubMed economies under review have been part of the euro area, and therefore they could not conduct autonomous monetary policy. Moreover, they chose to address the fiscal challenges by taking the traditional route of cutting expenditures and raising taxes (to adjust their formerly unsustainably loose fiscal stance). By contrast, Hungary undertook a tax reform instead of raising taxes, and spent the fiscal savings on fostering employment. The fiscal reforms after 2010 were also supported by the monetary policy turnaround of the Magyar Nemzeti Bank in 2013, creating a vital and close coordination between the two main branches of economic policy (Lentner 2017). In addition to the interest rate cuts aiming at reaching the inflation target, SME lending, financial stability and the reduction of external indebtedness were 
supported by innovative, targeted measures. These structural changes paved the way for sustainable economic growth. Nonetheless, in order to ensure successful convergence, the focus should shift to further improving the qualitative (i.e. nonprice) competitiveness of the economy.

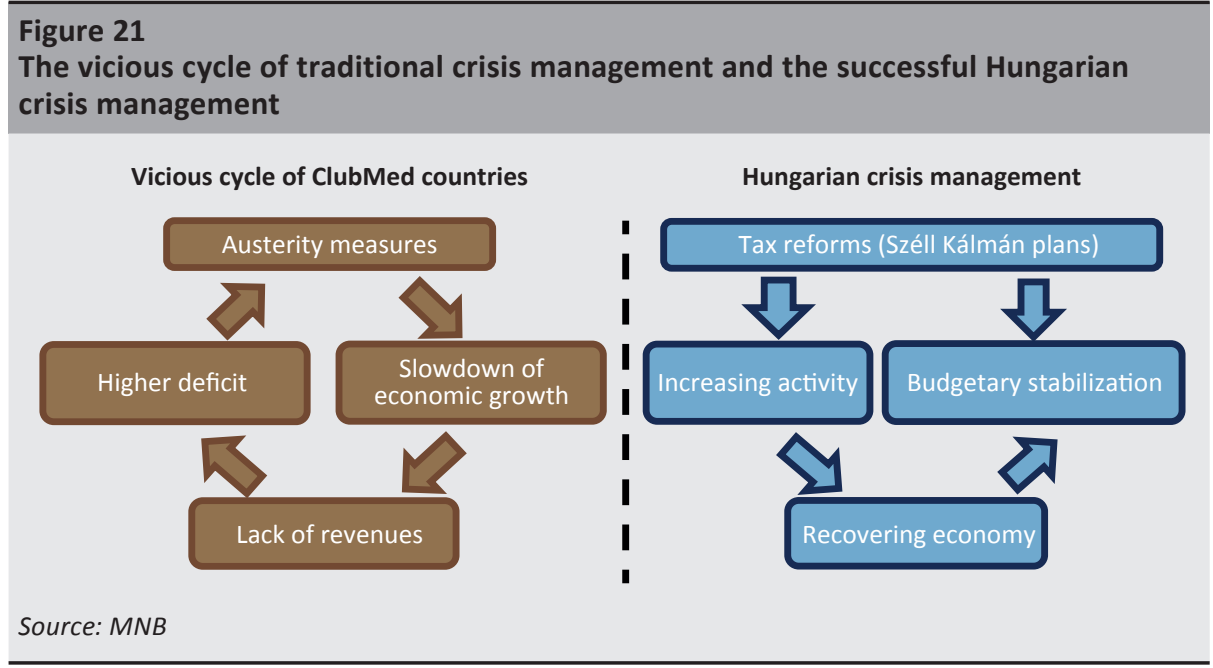

In contrast to the successful stabilisation in Hungary based on targeted, structural reforms, the crisis management of the Mediterranean euro area countries proved to be unsuccessful. This was mainly attributable to fiscal austerity, and the lack of structural reforms and an autonomous, targeted and efficient monetary policy. The belated and inefficient monetary crisis management and the traditional fiscal crisis management based on austerity measures entailed enormous real economy sacrifices, which led to a vicious cycle in the economy. As a result, the Mediterranean countries still struggle with growth and labour market conditions worse than before the crisis and high and stagnating government debt levels. We believe that if during the crisis the ClubMed countries had undertaken reforms similar to the Hungarian way after 2010 , they would have been able to achieve fiscal stability and labour market consolidation sooner and with a smaller growth sacrifice.

\section{References}

Auerbach, A.J. - Gorodnichenko, Y. (2012): Measuring the Output Responses to Fiscal Policy. American Economic Journal: Economic Policy, 4(2): 1-27. https://doi.org/10.1257/pol.4.2.1

Banai, P.B. - Palotai, D. (2018): Fenntartható költségvetés - fenntartható nyugdíjrendszer (Sustainable budget - sustainable pension system). Világgazdaság, 8 February.

Blanchard, O. - Leigh, D. (2013): Growth Forecast Errors and Fiscal Multipliers. IMF working paper. 
Lentner, Cs. (2017): Scientific Taxonomy of Hungarian Public Finances After 2010. Civic Review, 13 (Special Issue): 21-38. https://doi.org/10.24307/psz.2017.0303

Demertzis, M. - Wolff, G.B. (2016): The effectiveness of the European Central Bank asset purchase programme. Bruegel Institute, May.

European Commission (2011): Tax reforms in EU Member States. http://ec.europa.eu/ economy_finance/publications/european_economy/2011/pdf/ee-2011-5_en.pdf

European Commission (2013): Study on the impacts of fiscal devaluation. Taxation papers, Working paper No. 36.

European Commission (2017): Study and Reports on the VAT Gap in the EU-28 Member States. 2017 Final Report. https://ec.europa.eu/taxation_customs/sites/taxation/files/ study_and_reports_on_the_vat_gap_2017.pdf

Eyraud, L. - Weber, A. (2013): The Challenge of Debt Reduction during Fiscal Consolidation. IMF Working Paper, 13/67. https://doi.org/10.5089/9781475553864.001

House, C. - Proebsting, C. - Tesar, L. (2017): Austerity in the Aftermath of the Great Recession. NBER Working Papers Series No. 23147. https://doi.org/10.3386/w23147

Ilzetzki, E. - Mendoza, E.G.- Végh, C.A. (2013): How Big (Small?) are Fiscal Multipliers? Journal of Monetary Economics, 60(2): 239-254. https://doi.org/10.1016/j.jmoneco.2012.10.011

Kolozsi, P.P. - Banai, Á. - Vonnák, B. (2015): Phasing out household foreign currency loans: schedule and framework. Financial and Economic Review 14(3): 60-87. http://english. hitelintezetiszemle.hu/letoltes/3-kolozsi-banai-vonnak-en.pdf

Kolozsi, P.P. - Lentner, Cs. - Parragh, B. (2017): Közpénzügyi megújulás és állami modellváltás Magyarországon (Revised public finances and a new governmental model in Hungary). Polgári Szemle, 13(4-6): 28-51. https://polgariszemle.hu/aktualis-szam/146allampenzugyi-muhely-nemzetgazdasagtan/917-kozpenzugyi-megujulas-es-allamimodellvaltas-magyarorszagon

Lehmann, K. - Mátrai, R. - Pulai, Gy. (2013): Measures taken by the Federal Reserve System and the European Central Bank during the crisis. MNB Bulletin, Special Issue, October 2013: 100-109.

Magyar Nemzeti Bank (2015): The Magyar Nemzeti Bank's Self-Financing Programme, April 2014-March 2015. Magyar Nemzeti Bank. http://www.mnb.hu/letoltes/the-magyarnemzeti-bank-s-self-financing-programme-april-2014-march-2015.pdf

Magyar Nemzeti Bank (2016): Mid-term Report 2013-2016. https://www.mnb.hu/letoltes/ felidos-jelentes-2013-2016-eng-0623.pdf 
Magyar Nemzeti Bank (2017): The Hungarian Way - Targeted Central Bank Policy. Magyar Nemzeti Bank Book Series, Magyar Nemzeti Bank.

Matolcsy, Gy. (2008): Éllovasból sereghajtó - Elveszett évek krónikája (From Vanguard to Bringing Up the Rear - A Chronicle of Lost Years). Éghajlat Könyvkiadó Kft., Budapest.

Matolcsy, Gy. (2015): Economic Balance and Growth. Magyar Nemzeti Bank Book Series, Kairosz Könyvkiadó Kft.

Matolcsy, Gy. (2017): Tíz évvel a válság után 2007-2017 (Ten years after the crisis 20072017). Presentation at the plenary session of the 2017 Annual Congress of Economists of the Hungarian Economic Association, 7 September. http://www.mkt.hu/wp-content/ uploads/2017/09/nyito_Matolcsy_Gyorgy.pdf

Matolcsy, Gy. - Palotai, D. (2016): The interaction between fiscal and monetary policy in Hungary over the past decade and a half. Financial and Economic Review, 15(2): 5-32. http://english.hitelintezetiszemle.hu/letoltes/gyorgy-matolcsy-daniel-palotai-en.pdf

Mosberger, P. (2017): Egykulcsos társasági adó hatása (The impact of a flat-rate corporate tax). Szakmai cikk (Article), MNB, https://www.mnb.hu/letoltes/mosberger-palmaegykulcsos-tarsasagi-ado-hatasa.pdf

Nagy, M. (2015): Forintosítás - hogy is volt ez? (Forint conversion - How did it exactly go?) Szakmai cikk (Article), MNB. https://www.mnb.hu/letoltes/15-01-28-nagy-marton-istvanforintositas-hogy-is-volt-ez.pdf

Nagy, M. - Virág, B. (2017): Felzárkózás az eurozónában - csakis megfelelő felkészültséggel teljesithetö. (Convergence in the euro area - Achievable only with the appropriate preparation). Szakmai cikk (Article), MNB. https://www.mnb.hu/letoltes/nagy-martonvirag-barnabas-felzarkozasi-az-eurozonaban-frissitett.pdf

OECD (2010): Tax Policy reform and Economic Growth. OECD Tax Policy Studies 20. OECD Publishing, Paris.

OECD (2017): OECD Tax database. http://www.oecd.org/tax/tax-policy/tax-database. htm\#VATTables

Palotai, D. (2017): Beértek a 2010-2013 közötti adóreform kedvezö hatásai (The favourable effects of the 2010-2013 tax reform have borne fruit). Szakmai cikk (Article), MNB. https://www.mnb.hu/letoltes/palotai-daniel-adoreform-gyumolcsei-mnb-honlapra.pdf

Prammer, D. (2011): Quality of taxation and the crisis: tax shifts from a growth perspective. Taxation papers NO. 29, European Commission.

Sapir, A. (2016): The eurozone needs less heterogenity. Vox article, 12/01/2016. https://voxeu.org/article/eurozone-needs-less-heterogeneity 
Sávai, M. - Kiss, G.D. (2017): Az államadósság mértékét meghatározó mutatók vizsgálata. A V4 és GIPS országcsoportok összehasonlító elemzése egylépéses dinamikus panelregresszió segítségével (Examination of Indicators Determining the Rate of Government Debt. Comparative Analysis of the V4 and GIPS Countries Using One-step Dynamic Panel Regression). Pénzügyi Szemle, 2017(4): 445-461. https://www.penzugyiszemle.hu/ documents/savaim-kissgd-2017-4-mpdf_20180110163634_5.pdf

Szalai, Á. - Kolozsi, P.P. (2016): Mit kell tennünk egy versenyképesebb magyar gazdaságért? Gondolatok a Magyar Nemzeti Bank Versenyképesség és növekedés címü monográfiájával kapcsolatban (What Shall We Do for a More Competitive Hungarian Economy? - Thoughts About the Monograph Competitiveness and Growth of the Magyar Nemzeti Bank). Polgári Szemle, 12(4-6).

Szoboszlai, M. - Bögöthy, Z. - Mosberger, P. - Berta, D. (2018): A 2010-2017 közötti adó- és transzferváltozások elemzése mikroszimulációs modellel (Analysis of the changes in the tax and transfer system in 2010-2017 using a microsimulation model). MNB Occasional Papers - 135., February. https://www.mnb.hu/letoltes/mnb-tanulma-ny-135-vegleges.pdf

Trabandt, M. - Uhlig, H. (2012): How do Laffer curves differ across countries? WP No. 17862, National Bureau of Economic Research, February. http://www.nber.org/papers/w17862.pdf 